\title{
HIGH LEVEL WASTE IMMOBILIZATION FORMS
}

L. L. Hench and D. E. Clark

Department of Materials Science and Engineering, University of Florida, Gainesville, Florida 32611, USA

J. Campbell

Lawrence Livermore National Laboratory, P.O. Box 5580, L-482, Livermore, California 94550, USA

ABSTRACT. Various solid HLW forms compared for leach resistance, irradiation stability, processing, and physical properties yield alkali borosilicate glass and titanate based ceramics as leading waste forms. Titanates offer the possibility of higher waste loading. Glass waste forms offer the advantage of simpler and demonstrated full-scale and radioactive remote processing operations. Predictions of glass-repository performance based upon leaching kinetics, solubility limits, thermodynamics, and multiple films are confirmed by in situ burial tests.

\section{INTRODUCTION}

Research on high level waste (HLW) forms began in the 1950 s and 1960 s with investigations of borosilicate- $(1,2)$, phosphate- $(3)$, and nepheline-syenite- (4) based glasses and a variety of polyphase ceramic $(5,6)$, bituminous, and concrete (7) materials. Based upon extensive evaluations of alternative waste forms (8-15), borosilicate glass and titanate-based polyphase ceramics were selected (8) in 1982 as the reference and alternative forms for continued development and evaluation in the United States High Level Waste Program (HLW), with a specific ceramic form, Synroc-D, designated as the alternative waste form for Savannah River Plant (SRP) wastes. Both the glass and the polyphase ceramic forms were considered viable candidates for use at each of the Department of Energy (DOE) defense waste sites and also potential candidates for immobilization of commercial reprocessing wastes (8).

This paper reviews the waste form evaluation process and discusses the processing, characteristics, physical properties, and leach resistance of borosilicate glass and Synroc waste forms. The current status of understanding the interactions of glass waste forms with various components of a repository HLW storage system is also reviewed.

Because of radioactive decay, an HLW form generates heat. Since a repository serves as a thermal insulator, the heat generated by a waste canister results in a temperature rise of the canister. The equi-

ReCEIVED 4/20/84; ACCEPTED 7/17/84.

Acknowledgements - The preparation of this manuscript was funded by the U.S. Department of Energy. librium temperature of a canister is a function of the canister dimensions, properties of the host rock, boundary conditions, percentage of waste loading, age of the waste, post burial time, etc. Since the primary source of heat is the radioactive decay of $\mathrm{Cs}$ and $\mathrm{Sr}$ isotopes, which are relatively short lived, the thermal period of storage lasts for only 300 to $500 \mathrm{yr}$ post burial. Temperatures during the post-thermal period are largely dictated by the ambient temperature of the repository. Consequently, waste form performance in the post-thermal period will generally depend upon leaching resistance in 10 to $40^{\circ} \mathrm{C}$ water saturated with the constituents of the repository rock and any reacted canister, overpack, and backfill materials used in the storage system.

It is only during the first few hundred years of the thermal period that canister temperatures can be as high as 90 to $250^{\circ} \mathrm{C}$. Waste forms that contain defense wastes or low $(10 \%-15 \%)$ weight percentages of commercial waste or commercial wastes from extended interim storage should generate relatively little heat (300-700 W/canister), and consequently burial temperatures will generally not exceed $90^{\circ} \mathrm{C}$, even during the thermal period. Therefore, a $90^{\circ} \mathrm{C}$ limit is used for many of the leach tests reviewed herein. These data, however, serve only as an upper range for performance, since long-term geologic disposal will generally expose the waste form to water at temperatures of $40^{\circ} \mathrm{C}$ or lower.

\section{HIGH LEVEL WASTE FORMS}

In the United States, as many as 17 various waste forms (Table 1) have been considered as potential media for the geologic disposal of high level nuclear 
TABLE 1

Candidate Waste Forms Considered for Geologic Disposal of High Level Waste

\begin{tabular}{ll}
\hline \multicolumn{1}{c}{ Waste Form } & \multicolumn{1}{c}{ Comments } \\
\hline Borosilicate Glass & Primary International Waste Form, U.S. Reference Waste Form \\
Synroc-C, D & Alternative U.S. Waste Form \\
Tailored Ceramic & Semi-finalist U.S. Alternative Waste Form \\
High Silica Glass & Semi-finalist U.S. Alternative Waste Form \\
FUETAP Concrete & Semi-finalist U.S. Alternative Waste Form \\
Coated Sol-Gel Particles & Semi-finalist U.S. Alternative Waste Form \\
Glass Marbles in a Pb Matrix & Semi-finalist U.S. Alternative Waste Form \\
Phosphate Glass & Eliminated from U.S. Development in 1979-80 \\
Clay-Ceramic & Eliminated from U.S. Development in 1979-80 \\
Titanate Ion Exchanger & Eliminated from U.S. Development in 1979-80 \\
Stabilized Calcine & Eliminated from U.S. Development in 1979-80 \\
Pelletized Calcine & Eliminated from U.S. Development in 1979-80 \\
Normal Concrete & Eliminated from U.S. Development in 1979-80 \\
Hot-Pressed Concrete & Eliminated from U.S. Development in 1979-80 \\
Matrix Forms & Eliminated from U.S. Development in 1979-80 \\
Cermet & Eliminated from U.S. Development in 1979-80 \\
Disc-Pelletized Coated Particles & Eliminated from U.S. Development in 1979-80 \\
(For descriptions, processing, and relative merits, see refs. 8-15.) \\
\hline
\end{tabular}

wastes (8). During 1980, research and development activities for 10 of the forms were terminated based upon reviews $(9,10)$ which raised technical concerns about the viability of these forms as candidates for geologic disposal of wastes. Following one year of continued development and characterization, the seven remaining forms (Table 1) were given four different assessments by a U.S. Department of Energy (DOE) evaluation team: [1] evaluations at DOE defense waste-sites (8), [2] peer review evaluation (11), [3] product performance evaluation (12), and [4] a processibility analysis (13). A description of the evaluation process, performance indices, weighting factors, processibility factors, and selection criteria are reviewed in the work edited by Bernadzikowski (8). Based upon the combined results of these four inputs, two of the seven forms - borosilicate glass and titanate based polyphase ceramics - were selected (8) as the reference and alternative forms for the U.S. Defense HLW Program.

In 1981, the French CEA group also selected borosilicate glass for the solidification of fission product solutions at the commercial waste reprocessing facility at La Hague (15). The French decision was based in part on the successful operation of the PIVER HLW vitrification pilot installation since 1973 and the AVM prototype HLW vitrification plant at Marcoule since June 1978 (16). As of May 20, 1981, the French HLW vitrification facility had produced 506 glass containers corresponding to $375 \mathrm{~m}^{3}$ of reprocessed solutions of fission products equal to $5.8 \times 10^{7}$ Ci. The containers are $1 \mathrm{~m}$ high $\times 0.5 \mathrm{~m}$ diam. (15).

Processibility analyses of various waste forms in the U.S. program led to a factor of 2 to 4 times advantage for borosilicate glass as a waste form over polyphase ceramics $(8,13,14)$. This processing advantage for glass was largely due to the simplicity of a slurry-fed glass melter demonstrated in a prototype plant at Savannah River Laboratory (SRL) (17-19). Successful operation of a calcine-fed and slurry-fed glass melter in remote operations at SRL confirms the French findings, and the AVM program has proven that routine solidification of high level wastes is possible with the use of alkali borosilicate glass. However, the relative economics of glass as compared with polyphase ceramic waste forms for solidification of commercial HLW wastes is still under debate (20-22). This is because the waste loading (as volume \%) of ceramic forms is three times that of the reference SRL glass which gives Synroc-D potential economic advantage for interim storage, transportation, and repository storage $(21,22)$, if higher storage temperatures are acceptable.

\section{BOROSILICATE GLASS AS A HLW FORM}

The concept of using glass as a host for radioactive wastes is based upon the radionuclides entering into and becoming part of the random three-dimensional glass network. Figure 1 illustrates schematically a portion of an alkali borosilicate glass network containing various radionuclides as constituents. The structural framework of the glass is provided primarily by the $\mathrm{SiO}_{4}^{4-}$ tetrahedra. Neighboring silicate tetrahedra are bonded together by sharing strong ionic-covalent bridging oxygen bonds. Other multi- 


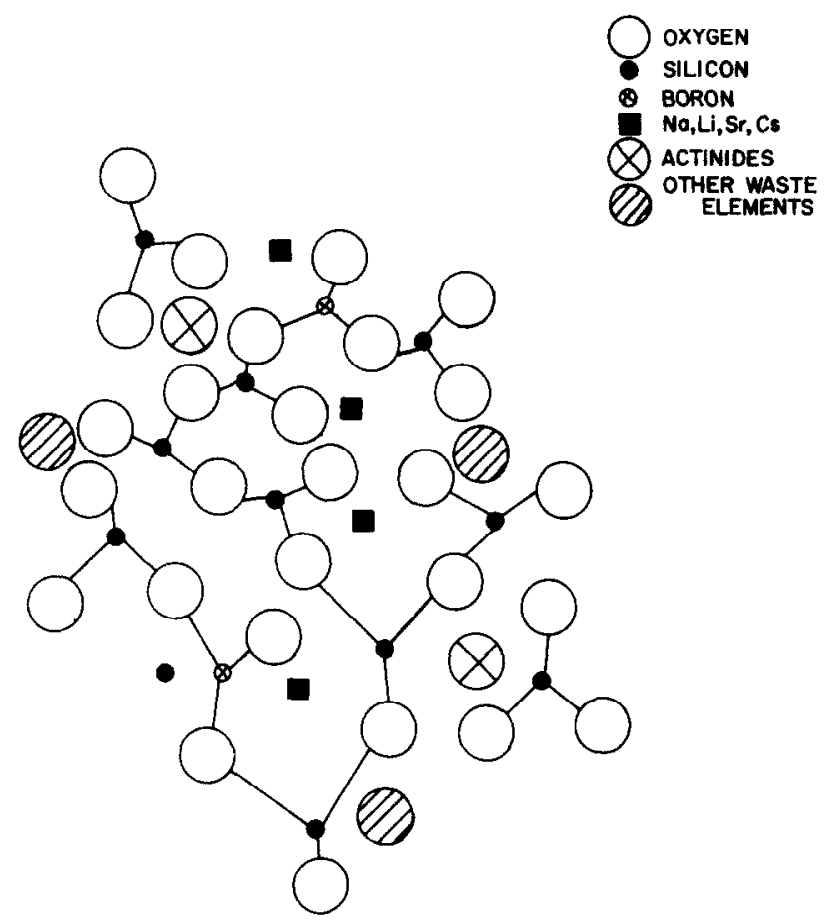

FIGURE 1. Glass structure containing dissolved wastes. valent species such as $\mathrm{B}^{3+}, \mathrm{Fe}^{(+2+3)}$, rare earths, or actinides are also generally bonded within the network by bridging oxygen bonds. Low valence ions such as $\mathrm{Na}^{+}, \mathrm{Cs}^{+}, \mathrm{Sr}^{+2}$, etc., are bonded into the network by sharing various nonbridging oxygen bonds depending upon size of the ion. This difference in type of bonding in the glass network is responsible for the complex leach behavior of nuclear waste glasses, but also leads to low leach rates for certain ranges of glass-waste compositions.

At low (10-35 weight \%) loadings of waste in glass, most of radionuclides in the form of oxides dissolve in the glass structure, some contributing to formation of the glass network and some held within the network (Fig. 1). However, if the concentration of certain waste elements, such as Ru or Mo, is too high, they will form a second phase and not dissolve in the glass. Optimized nuclear waste glass compositions have little or no second phases resulting from inconlplete dissolution or devitrification $(17,19)$. However, depending upon annealing schedules, spinel ( $\mathrm{Ni}, \mathrm{Fe}$, Mn) $\mathrm{Fe}_{2} \mathrm{O}_{4}$ and acmite can form in SRL glass (19).

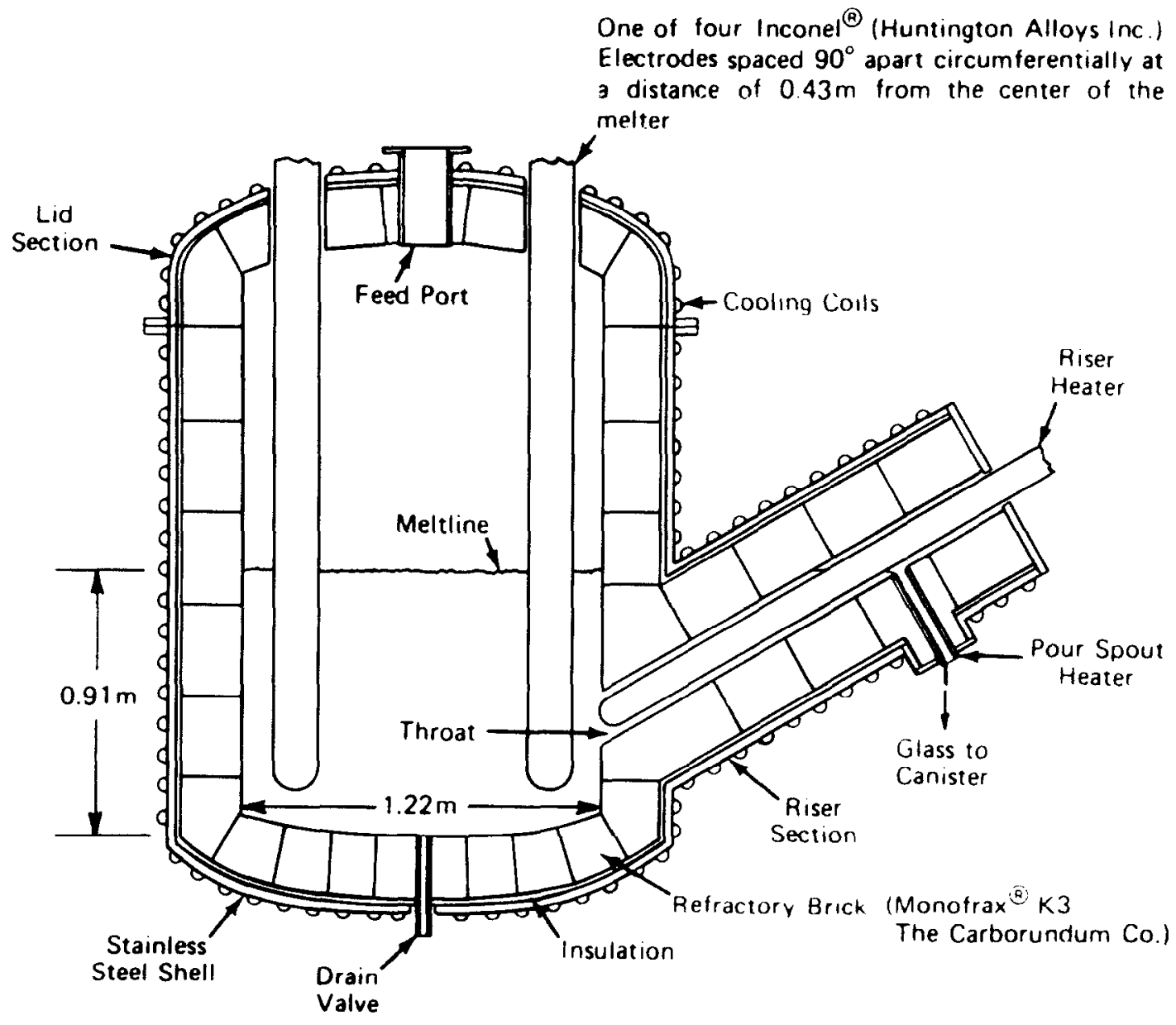

FIGURE 2. Slurry-fed melter for vitrification of nuclear wastes. (Courtesy G. Wicks) 
TABLE 2

Simulated Borosilicate Nuclear Waste Glass Compositions

\begin{tabular}{|c|c|c|c|c|c|c|}
\hline \multirow{3}{*}{ Components } & \multicolumn{6}{|c|}{ Glass Designation } \\
\hline & PNL 76-68 & SRL 131 & SRL 165 & ABS 39 & ABS 41 & JSS \\
\hline & \multicolumn{6}{|c|}{ Weight Percent of Component } \\
\hline $\mathrm{SiO}_{2}$ & 38.3 & 40.6 & 47.7 & 48.5 & 52.0 & 45.52 \\
\hline $\mathrm{B}_{2} \mathrm{O}_{3}$ & 9.2 & 10.3 & 7.0 & 19.1 & 15.9 & 14.04 \\
\hline $\mathrm{Li}_{2} \mathrm{O}$ & - & 4.0 & 4.9 & - & 3.0 & 1.98 \\
\hline $\mathrm{Na}_{2} \mathrm{O}$ & 7.3 & 12.4 & 9.1 & 12.9 & 9.4 & 5.42 \\
\hline $\mathrm{K}_{\mathbf{2}} \mathrm{O}$ & - & - & - & - & - & \\
\hline $\mathrm{TiO}_{2}$ & 2.9 & 0.7 & - & - & - & \\
\hline $\mathrm{CaO}$ & 1.9 & - & - & - & - & 4.03 \\
\hline $\mathrm{MgO}$ & - & 1.4 & 0.7 & - & - & \\
\hline $\mathrm{BaO}$ & - & - & - & - & - & \\
\hline $\mathrm{Al}_{2} \mathrm{O}_{3-}$ & - & - & - & 3.1 & 2.5 & 1.97 \\
\hline $\mathrm{ZnO}$ & 4.9 & - & - & - & 3.0 & 2.51 \\
\hline $\mathrm{ZrO}_{2}$ & - & 0.4 & 0.7 & - & - & 0.54 \\
\hline $\mathrm{La}_{2} \mathrm{O}_{3}$ & - & 0.4 & - & - & - & \\
\hline $\mathrm{Rb}_{2} \mathrm{O}$ & 0.12 & - & - & - & - & - \\
\hline $\mathrm{SrO}$ & 0.36 & 0.14 & 0.14 & 0.26 & 0.26 & 0.33 \\
\hline $\mathrm{Y}_{2} \mathrm{O}_{3}$ & 0.20 & - & - & 0.152 & 0.152 & 0.19 \\
\hline $\mathrm{ZrO}_{2}$ & 1.77 & - & - & 1.29 & 1.29 & 1.62 \\
\hline $\mathrm{MoO}_{3}$ & 2.17 & - & - & 1.65 & 1.65 & 2.06 \\
\hline $\mathrm{RuO}_{2}$ & 1.02 & - & - & - & - & - \\
\hline $\mathrm{Rh}_{2} \mathrm{O}_{3}$ & 0.17 & - & - & - & - & - \\
\hline $\mathrm{PdO}$ & 0.51 & - & - & - & - & - \\
\hline $\mathrm{Ag}_{2} \mathrm{O}$ & 0.03 & - & - & 0.01 & 0.01 & 0.01 \\
\hline $\mathrm{CdO}$ & 0.03 & - & - & 0.03 & 0.03 & 0.03 \\
\hline $\mathrm{TeO}_{2}$ & 0.25 & - & - & - & - & - \\
\hline $\mathrm{Cs}_{2} \mathrm{O}$ & 0.99 & 0.09 & 0.09 & 0.89 & 0.89 & 1.11 \\
\hline $\mathrm{BaO}$ & 0.54 & - & - & 0.46 & 0.46 & 0.58 \\
\hline $\mathrm{La}_{2} \mathrm{O}_{3}$ & 0.51 & - & - & 0.72 & 0.72 & 0.90 \\
\hline $\mathrm{CeO}_{2}$ & 1.15 & - & - & - & - & - \\
\hline $\mathrm{Pr}_{6} \mathrm{O}_{11}$ & 0.51 & - & - & - & - & - \\
\hline $\mathrm{Nd}_{2} \mathrm{O}_{3}$ & 1.60 & - & - & 1.22 & 1.22 & 1.53 \\
\hline $\mathrm{Sm}_{2} \mathrm{O}_{3}$ & 0.32 & - & - & - & - & - \\
\hline $\mathrm{Eu}_{2} \mathrm{O}_{2}$ & 0.07 & - & - & - & - & - \\
\hline $\mathrm{Gd}_{2} \mathrm{O}_{3}$ & 0.05 & - & - & - & - & - \\
\hline $\mathrm{U}_{3} \mathrm{O}_{8}$ & 4.39 & 1.1 & 1.1 & - & - & - \\
\hline $\mathrm{Cm}_{2} \mathrm{O}_{3}$ & 3.0 & - & - & - & - & - \\
\hline $\mathrm{MnO}_{2}$ & - & 3.9 & 3.9 & 0.78 & 0.78 & 0.97 \\
\hline $\mathrm{Na}_{2} \mathrm{SO}_{4}$ & - & 0.2 & 0.2 & - & - & - \\
\hline $\mathrm{Na}_{2} \mathrm{O}$ & 4.84 & 0.9 & 0.9 & - & - & 4.44 \\
\hline $\mathrm{Fe}_{2} \mathrm{O}_{3}$ & 9.38 & 13.4 & 13.4 & 5.7 & 3.6 & 2.91 \\
\hline $\mathrm{Cr}_{3} \mathrm{O}_{3}$ & 0.40 & - & - & - & - & 0.51 \\
\hline $\mathrm{NiO}$ & 0.20 & 1.6 & 1.6 & 0.37 & 0.37 & 0.87 \\
\hline $\mathrm{P}_{2} \mathrm{O}_{3}$ & 0.46 & - & - & - & - & 0.28 \\
\hline $\mathrm{Ca}_{2} \mathrm{O}_{3}$ & - & - & - & 0.76 & 0.76 & 0.95 \\
\hline $\mathrm{Pr}_{2} \mathrm{O}_{3}$ & - & - & - & 0.38 & 0.38 & 0.48 \\
\hline $\mathrm{Sb}_{2} \mathrm{O}_{3}$ & - & - & - & 0.004 & 0.004 & 0.005 \\
\hline $\mathrm{SnO}$ & - & - & - & 0.02 & 0.02 & 0.02 \\
\hline $\mathrm{UO}_{2}$ & - & - & - & 1.67 & 1.67 & 0.85 \\
\hline $\mathrm{Al}_{2} \mathrm{O}_{3}$ & - & 2.7 & 2.7 & - & - & 2.94 \\
\hline $\mathrm{SiO}_{2}$ & - & 1.2 & 1.2 & - & - & - \\
\hline $\mathrm{CaO}$ & - & 1.0 & 1.0 & - & - & - \\
\hline Zeolite & - & 2.9 & 2.9 & - & - & - \\
\hline Coal & - & 0.7 & 0.7 & - & - & - \\
\hline
\end{tabular}

Borosilicate Glass Processing

A principal advantage of a glass waste form is that it involves basically a one-step processing operation. Production of the glass waste form generally involves blending a low melting, nonradioactive glass powder, called frit, with the radioactive calcine or slurry and melting the two substances together to form a homogeneous network. (Table 2 lists some typical frit and 
waste compositions.) The glass frit waste mix can be melted and cast directly into a metal canister, or melted within the canister (Fig. 2). Such a simple process is obviously attractive for the remote canyon operations required for high-level wastes. Recent demonstrations of direct slurry feed of the glass melter by Wicks at SRL $(17,18)$ simplifies the processing even further by eliminating the calcination step used in the AVM process (15). This slurry-fed ceramic melting operation has also been demonstrated recently in the remote high-level caves at SRL (19).

\section{Nuclear Waste Glass Compositions}

The composition of borosilicate-based nuclear waste glasses has a marked effect on thermal stability and leaching, but is a relatively minor factor with respect to other physical properties. Until recently it has been difficult to determine the significance of nuclear waste glass compositional effects because equivalent test data from various laboratories were not available. However, with the worldwide adoption of MCC-1 static leach tests (23) for compositional screening studies, it is now possible to compare wide ranges of glass compositions with standardized leach results. A recent computerized comparison (24) of 27 nuclear waste glass compositions studied in four countries has been completed using results from $90^{\circ} \mathrm{C} \mathrm{MCC}-1$ static leach testing. Figure 3 illustrates the findings (24).

In the computer study, the glass compositions were divided into three groups; the weight percentage of oxides of $\mathrm{Si}, \mathrm{B}$, and $\mathrm{Na}$ are located at the top and right corners of the ternary plot. The oxides of $\mathrm{Al}$, $\mathrm{Fe}$, and all other constituents, labeled as WP (waste products) are added together and comprise the third axis. All of the glasses in the data file were enclosed within the compositional space labeled 45.0 in Fig. 3. Thus all 27 nuclear waste glasses stored have a leach rate for Si at 28 days of less than $45 \mathrm{~g} / \mathrm{m}^{2} \cdot$ day. A narrower, but still extensive, field of compositions possesses leach rates of $0.1-0.2 \mathrm{~g} / \mathrm{m}^{2} \cdot$ day. However, only a few compositions exhibit the low range of $0.02 \mathrm{~g} / \mathrm{m}^{2} \cdot$ day, and these contain a critical concentration range of $\mathrm{SiO}_{2}$ and other waste constituents.

The best compositional range of the 27 alkali borosilicate nuclear waste glasses is approximately $51 \%-53 \%\left(\mathrm{SiO}_{2}\right), 24 \%-28 \%\left(\mathrm{Na}_{2} \mathrm{O}+\mathrm{B}_{2} \mathrm{O}_{3}\right)$, and $21 \%-25 \%\left(\mathrm{Al}_{2} \mathrm{O}_{3}+\mathrm{Fe}_{2} \mathrm{O}_{3}+\mathrm{WP}\right)$. Computer analysis of the time-dependent changes of the compositional space for lowest leach rates leads to the conclusion that a critical concentration of $\mathrm{Al}_{2} \mathrm{O}_{3}, \mathrm{Fe}_{2} \mathrm{O}_{3}$, and waste product constituents are needed to produce

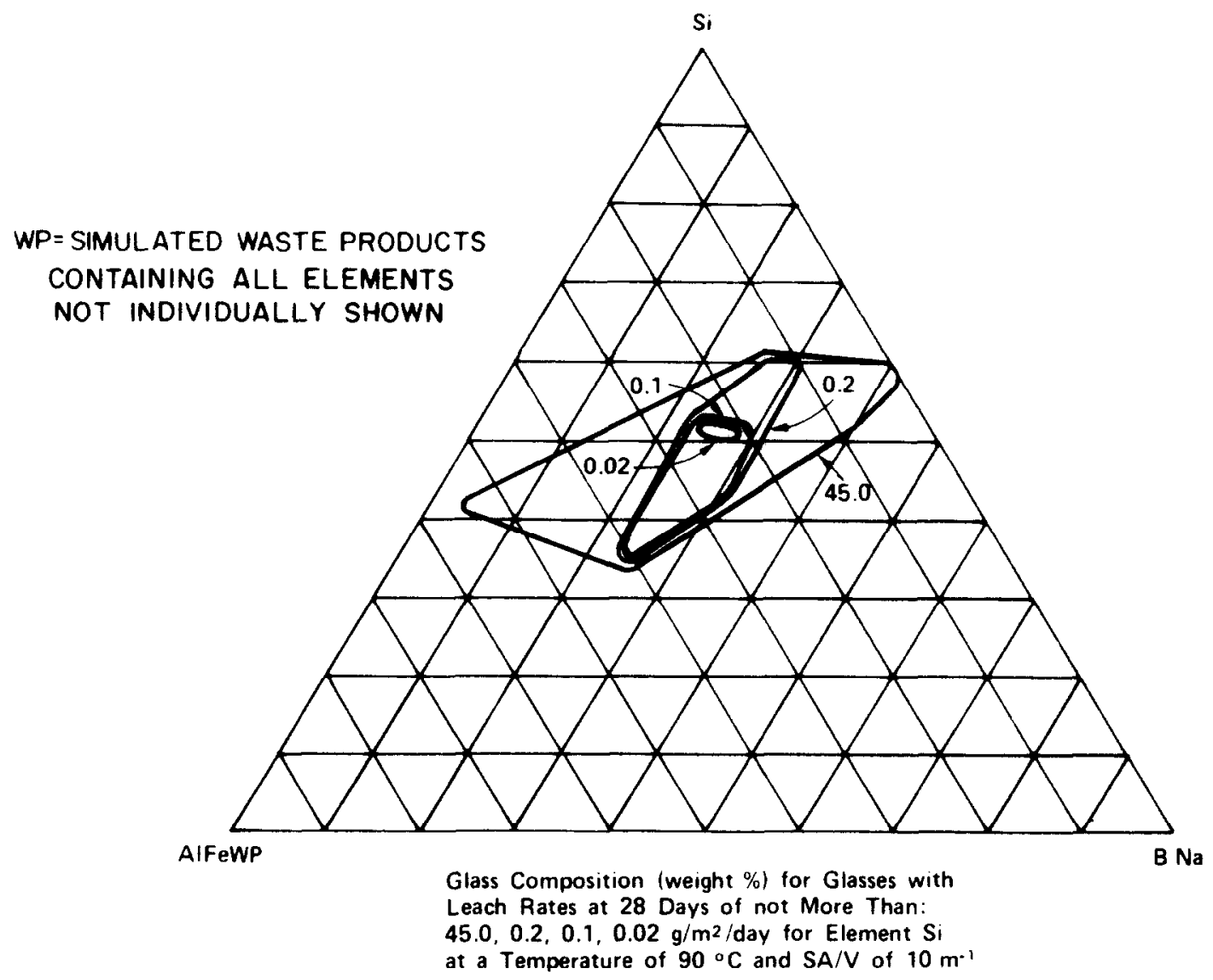

FIGURE 3. Ternary computer derived diagram illustrating compositional regions of constant leach rates (reference 24). 
low leach rates (24). This is consistent with surface analyses that show many of these species incorporated in surface films that form slowly and reduce long-term release rates of most species (Fig. 4) (25). This finding is also consistent with the conclusions from a comparison of a series of French nuclear waste glass compositions (26) and long-term leach studies in France (15).

One of the most positive factors in favor of glass as a waste form is the experimental evidence that the process is insensitive to possible variations in waste stream variability. Studies of borosilicate glasses containing actual radioactive wastes from the Savannah River Plant showed there was little difference in leach rates over 900 days even though the $\mathrm{Fe}, \mathrm{Al}, \mathrm{Mn}, \mathrm{Ca}$, and $\mathrm{Ni}$ content in the wastes varied from a factor of 2 to 3 (27). Similar results are reported for Marcoule glasses containing commercial wastes (15).

\section{NUCLEAR WASTE GLASS LEACH BEHAVIOR}

For some time, the primary issue of concern regarding glass and other HLW forms is their long-term stability in contact with hot repository ground waters in the event of a canister being breached. Thus, relative leach performance has been given the highest weighting factor in HLW form evaluation studies (8-14). Considerable effort has also been devoted to understanding the basic mechanisms and variables that control the rate of leaching of nuclear waste glasses (2). Consequently, we now know that the following fac- tors are important in controlling nuclear waste glass leaching within the storage system: glass composition and type of surface film formed; waste percent and type; leachant composition; temperature; ratio of surface area $(S A)$ of glass to volume $(V)$ of leachant $(S A / V)$; flow rate and leachant resident times; and canister, overpack, and backfill interactions.

Reasonably well-developed theories (28-30) and models (31-33) now exist that describe the leach behavior of nuclear waste glasses in terms of the above system variables. Quantitative surface analyses of leached nuclear waste glasses show that multiple layers form during laboratory or burial exposure to water $(25,28,29,34-38)$.

Glasses that form multiple layers on their surface during leaching are termed type III glasses (39). When the multiple layers of oxides or hydroxides are due to the solution exceeding solubility limits after network dissolution has occurred, the glass is termed a Type IIIB glass (28). The better alkali borosilicate nuclear waste glasses depicted in Fig. 3 behave as Type IIIB glasses.

Although a short (several days) period of alkalihydrogen ion exchange may occur for IIIB glasses, the dominant, long-term mechanism controlling corrosion is a combination of matrix dissolution followed by apparent incongruent dissolution and solution/precipitation reactions. The extent of matrix dissolution and onset of surface precipitation will depend on the time required for various species in the glass to reach saturation in solution. Saturation of

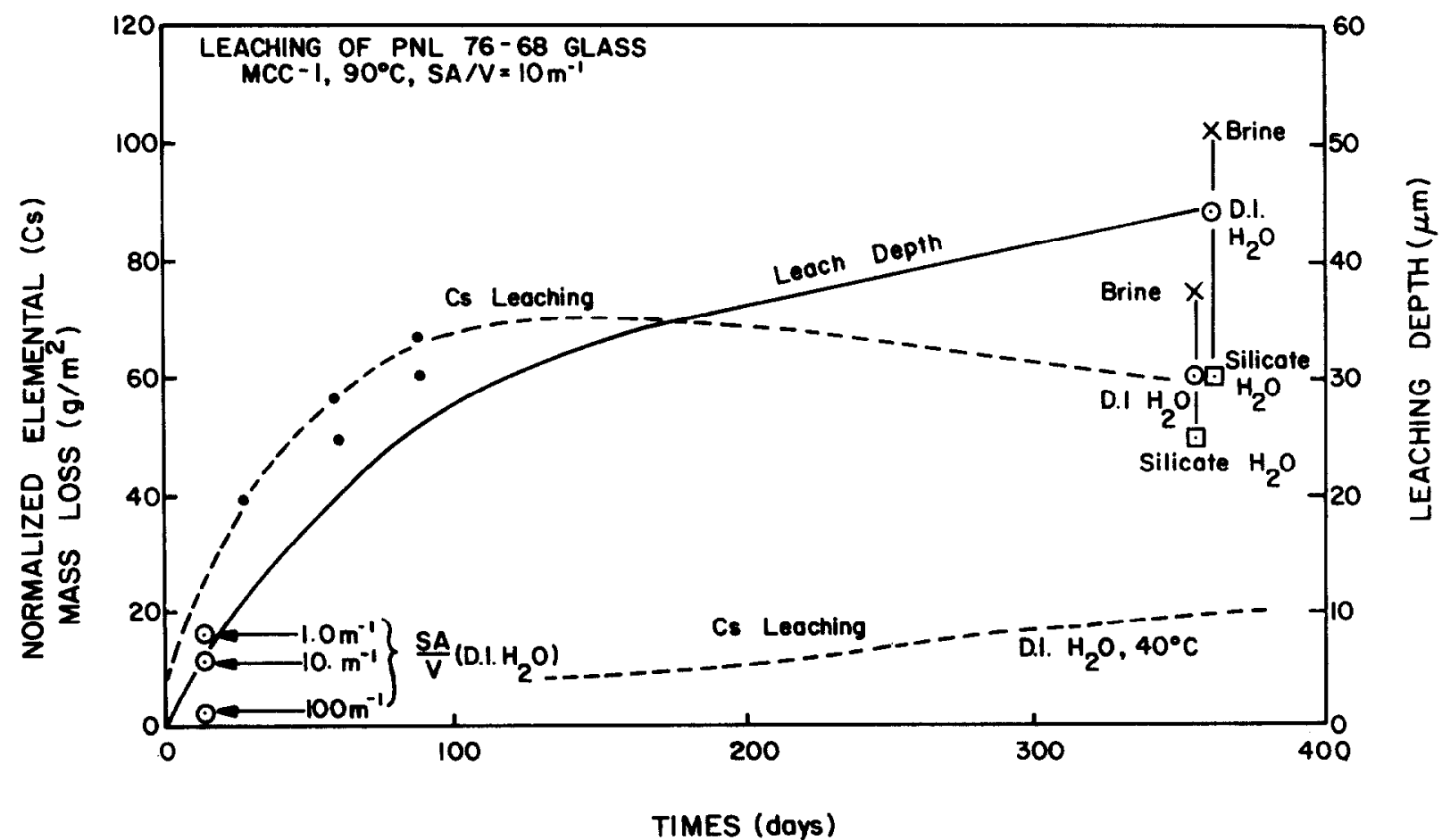

FIGURE 4. Gel layer thickness and normalized $C_{\boldsymbol{s}}$ mass loss for specimens leached in deionized water, silicate water, and brine solution and under three different $S A / V$ ratios (references 25 and 99 ). 
species $i$ will be a function of the initial solution $\mathrm{pH}$, amount of alkali in the glass and rate of alkali release, temperature, initial concentration of species $i$ in the solution, $S A / V$ which influences solution concentration, and flow rate which also affects solution concentration. Until saturation of some species in solution is reached, the glass dissolves congruently at a rate proportional to $k t^{1}$.

When solution saturation of species $i$ is reached, there is no longer any driving force for that species to leave the glass surface. Consequently, species $i$ will accumulate at the glass-solution interface as the matrix dissolves. If the matrix dissolution releases alkali ions, as will be the case for most glasses, there will be a concomitant rise in $\mathrm{pH}$ depending on the flow rate, or $S A / V$, and buffering capacity of the system.

An increase in $\mathrm{pH}$ can have several simultaneous effects on the glass, the solution, and the glass-solution interface. At the new $\mathrm{pH}$, a second species $j$ may reach solution saturation and subsequently be retained in the glass surface along with species $i$. The extent of apparent incongruent dissolution of the glass is thereby increased. In addition, the $\mathrm{pH}$ can have one of three effects on species $i$ previously in saturation: [1] it remains saturated, but at a higher concentration; [2] it becomes supersaturated and precipitates either on the glass, other surfaces, or as a colloid; or [3] it becomes undersaturated and once again is released from the glass. The sequence of events that occurs is predictable based upon the solubility limits of each species at a given $\mathrm{pH}$, as shown by Grambow (35).

Figure 5, based upon Grambow's work, shows that the $\mathrm{Fe}(\mathrm{OH})_{3}$ solubility limit should be exceeded over a broad range of $\mathrm{pH}$, and therefore nuclear waste glasses containing $\mathrm{Fe}$ oxides should concentrate $\mathrm{Fe}$ within surface layers. Zinc, Nd, Sr, and Ca should be concentrated as well in nearly neutral or slightly

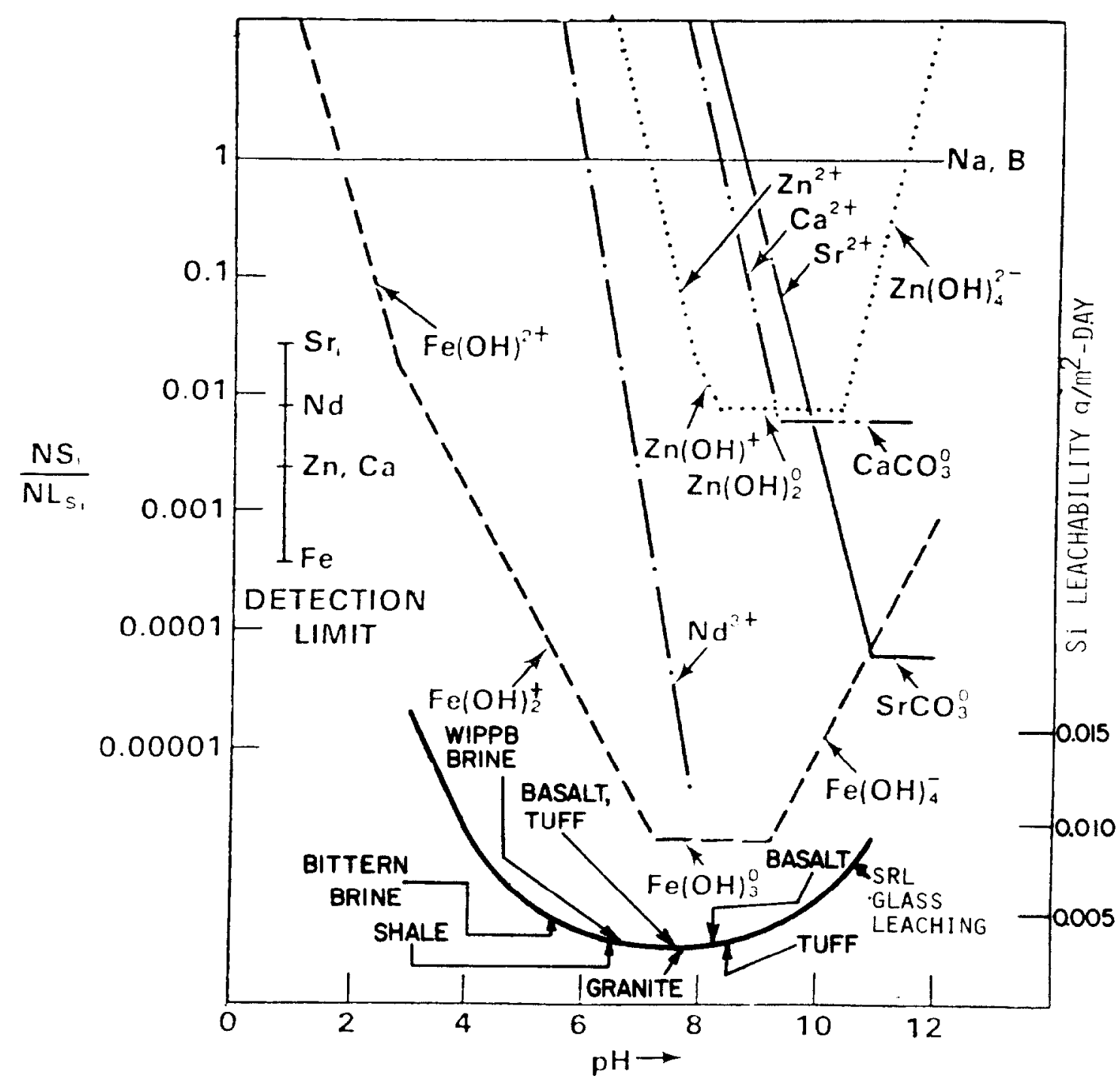

FIGURE 5. Correlation between solubility limits of nuclear waste glass surface reaction products and $23^{\circ} \mathrm{C}$ glass leach rates in different pH solutions (reference 28). 
alkaline solutions with $\mathrm{Na}$ and B depleted. Figures 6 and 7 obtained by electron microprobe analysis and AES profiling of corroded nuclear waste glasses (40), shows the concentration of Fe (Fig. 6) and other heavy metal species (Fig. 7) in the glass surface. Many other studies confirm the prediction of solubility limited surface layers $(34,41-45)$.

A consequence of the formation of the multiple barrier (Type IIIB) films is the low overall leachability of many nuclear waste glasses over a $\mathrm{pH}$ range from 4.5 to 9.5. Figure 5 superimposes a plot of $\mathrm{Si}$ leachability from a Savannah River Lab composite waste glass immersed in a 5 -day static $23^{\circ} \mathrm{C}$ solution buffered to various $\mathrm{pH}$ values from 3.5 to 10.7 . Wicks' (46) data shows that over the $\mathrm{pH}$ range expected for repository ground waters, shown by arrows, glass leachability is lowest. Thus, we can conclude that the solubility limits that establish the equilibrium ionic concentrations for the ground waters should also establish the multiple barrier films to protect nuclear waste glasses in contact with those ground waters. However, as discussed below, the effects of corroding canisters, overpacks, or backfills will alter the interfacial water chemistry and affect the glass surface as well.
It also has been shown by Wicks (47) that the thickness of Type IIIB films decreases with increasing percentage of waste constituents and multiple valence oxides. Leach rates for all elements are much lower for the glasses with thinner films; this indicates not only that the films formed quickly, but also that, for these glass compositions, the films were sufficiently continuous and dense to prevent extensive attack of the glass. It is especially important that burial studies of nuclear waste glasses in deep Swedish granite with $90^{\circ} \mathrm{C}$ centerline heaters have shown that Type IIIB surfaces form under conditions expected in long-term geologic repositories $(33,34,46,47)$. The presence of metallic overpack interfaces, such as $\mathrm{Pb}, \mathrm{Ti}$, or $\mathrm{Cu}$, accelerate formation of the multiple layers, apparently due to high surface area to solution volume ratios which lead to rapid precipitation of insoluble metallic compounds $(37,38)$. This can result in a substantially lower rate of surface depletion of elements from the glass, especially in the case of $\mathrm{Pb}$.

\section{Effects of Flow on Nuclear Waste Glass Leaching} The majority of glass and other HLW form corrosion research has involved the utilization of static

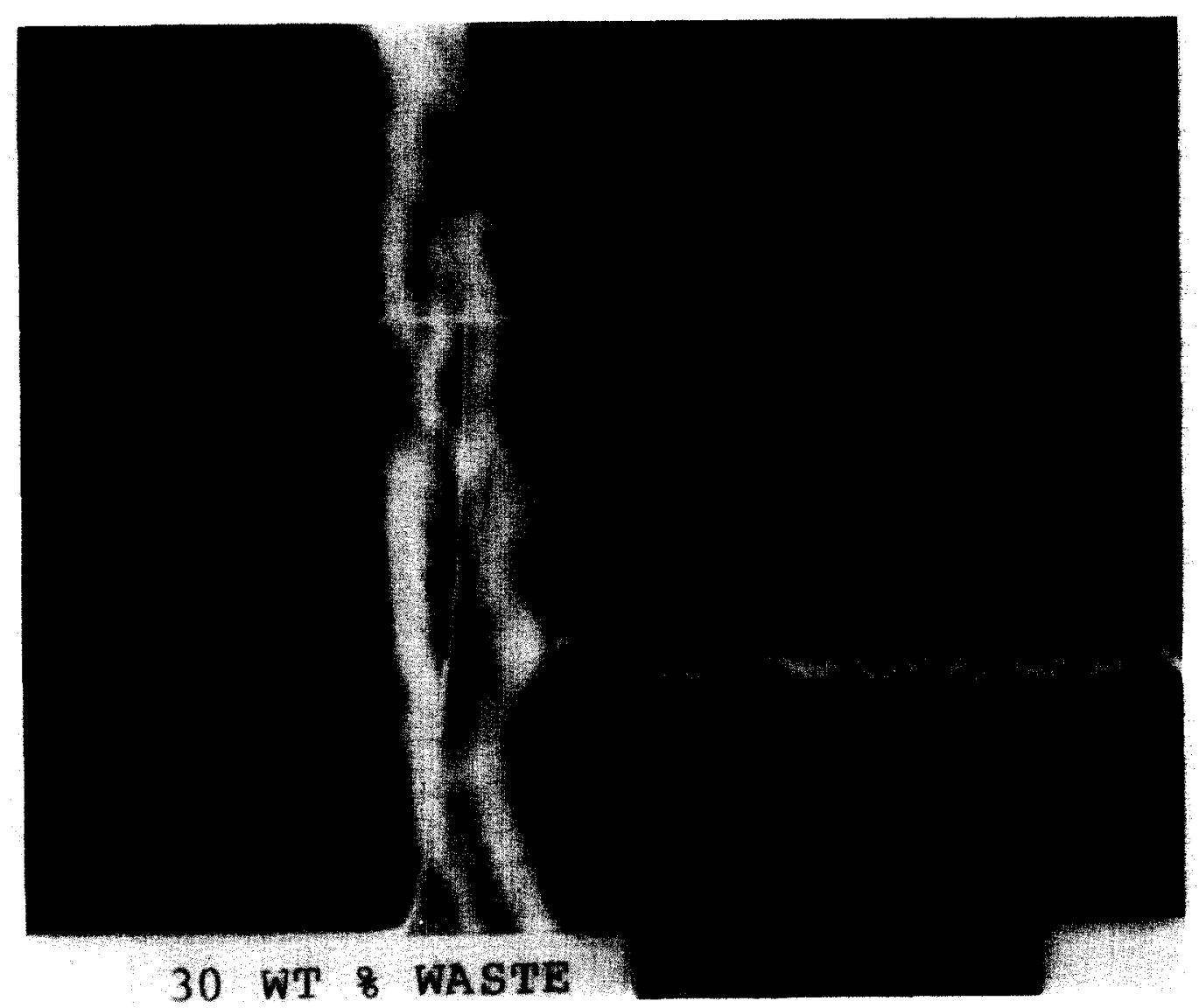

FIGURE 6. Cross section of waste glass illustrating the depth of surface alteration and concentration of iron in the surface of the glass (reference 47). 


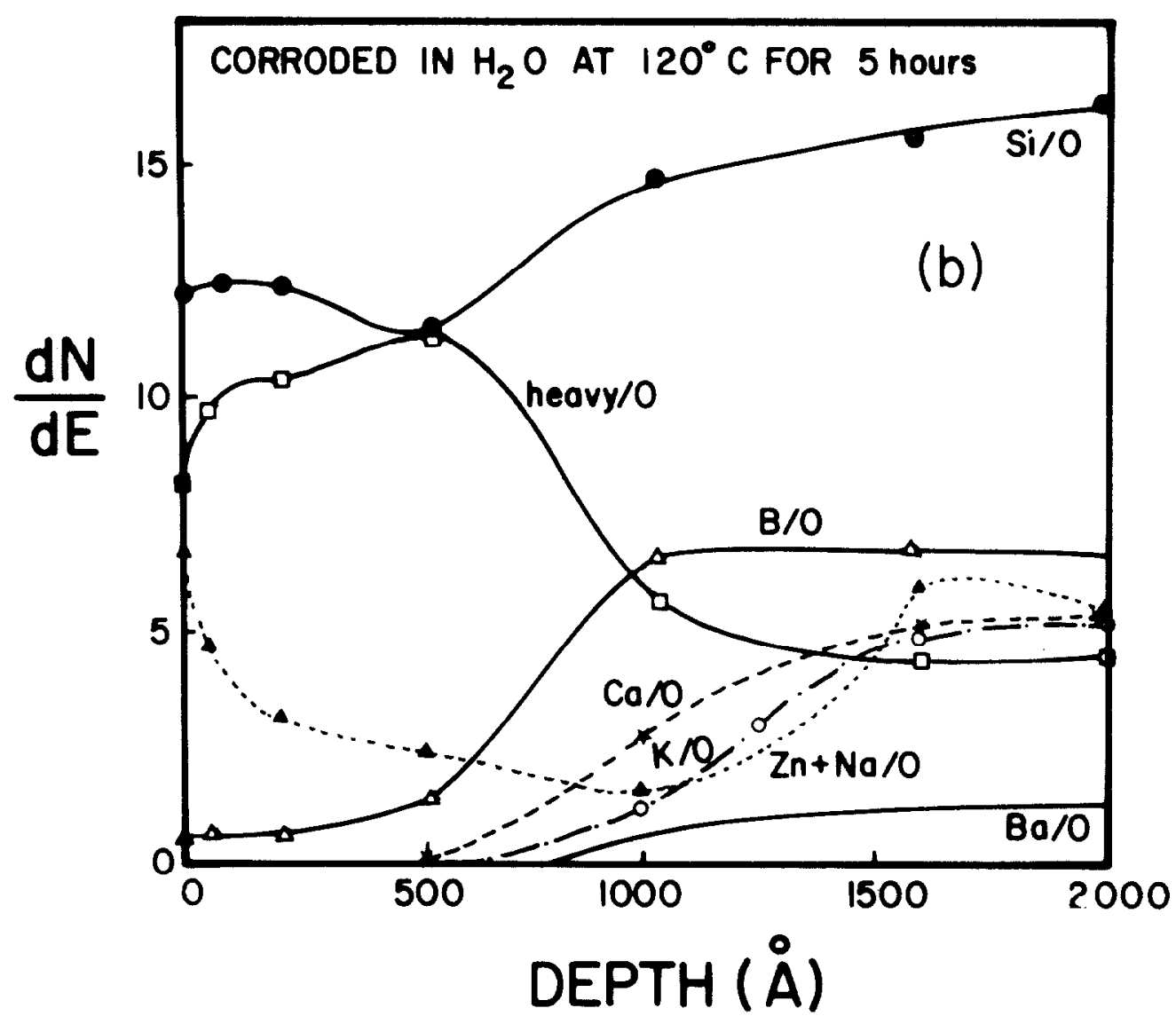

FIGURE 7. Depth compositional profile of surface of corroded 72-68 glass obtained with Auger electron spectroscopy (AES) coupled with $\mathrm{Ar}$ ion milling ( $\mathrm{dN} / \mathrm{dE}$ indicates the peak-to-peak height for each of the elements in the Auger spectrum) (reference 40 ).

testing, such as specified in MCC-1 (23). In this test, the samples are immersed in a cell containing a constant volume of solution. Although some liquid may escape over long exposure times due to evaporation, most of the original water remains in contact with the glass during testing, and there is no flow of solution into or out of the cell. Under certain conditions it is possible that groundwater will flow through a geological repository and react with its contents. Flow rates of up to several hundred $\mathrm{L} / \mathrm{yr}$ have been reported, but flow rates of only a few $\mathrm{L} / \mathrm{yr}$ are most probable. Additionally, potential accidents during transportation of the waste forms to the repository could lead to their exposure to flowing water.

In order to evaluate the effects of flow on waste form leaching, MCC-4 was developed by the Materials Characterization Center. This test is one in which the solution passes through the leaching vessel one time (i.e., single pass), and is similar to the test developed by Coles et al. (50). Strachan et al. (51) have reported increased leach rates for $\mathrm{Si}$ and $\mathrm{Sr}$ at a flow rate of $6 \mathrm{~mL} / \mathrm{h}$ compared to static testing. Similar results have been found by Jurgensen and Clark; these results are shown in Fig. 8. Based on weighing the samples before and after corrosion, the rate of leaching increased as the flow rate was increased from 0.1 to $10 \mathrm{~mL} / \mathrm{h}$. Little difference was observed between the static test and the test in which the flow rate was $0.1 \mathrm{~mL} / \mathrm{h}$.

Under high flow rates, corrosion products as well as potential surface-passivating species are removed from the leaching vessel, reducing the beneficial effects on both solution saturation and protective surface film formation. These results suggest that under the low flow conditions expected in the repository, saturation will prevail and the leach rate of the glass will be limited by the rate of transport of corrosion products from the repository. Similar conclusions have been reached by Macedo et al. (52) using a quasi-low flow test.

Other investigators have studied the effects on glass leaching by varying the flow rates in a recirculatory test in which the same solution is passed through the leaching vessel multiple times $(47,53)$. Under recirculating conditions, the extent of leaching decreases as flow rate increases. This difference between continuous flow and recirculating solutions is a result of protective surface films forming when the solution concentration of passivating ions increases, as occurs when the water recirculates. 


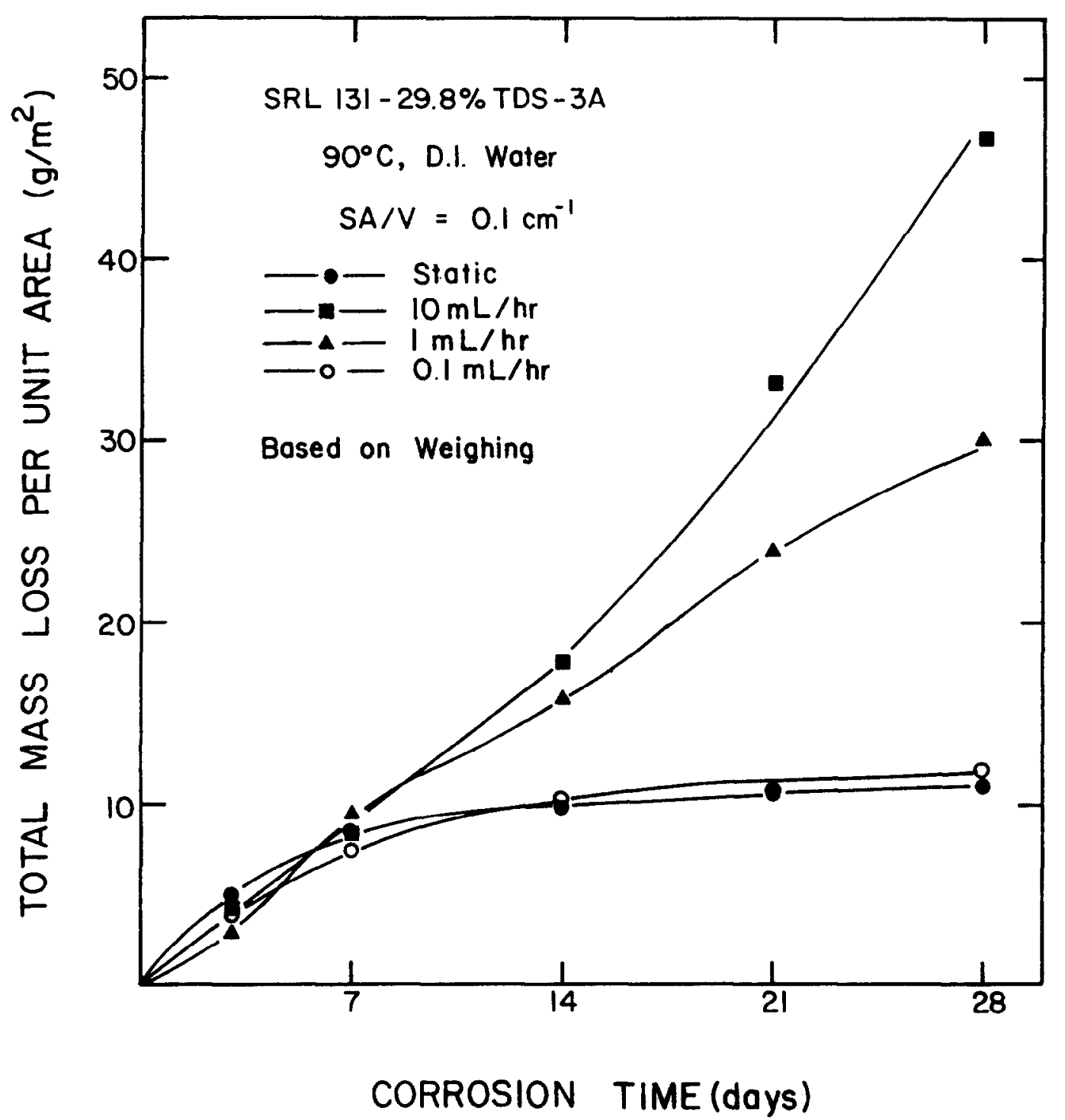

FIGURE 8. Effects of exposure time and flow rate on glass corrosion.

\section{Thermodynamic Approach to Nuclear Waste Glass}

\section{Leaching}

To date, most of the models developed for predicting glass leaching have been based on mechanistic considerations and kinetic equations. However, there have been several attempts to predict glass durability based on thermodynamic aspects of its chemical composition. Paul (54) showed that the thermodynamic stability of the component oxides in water could be used to predict the stability of glass in water. Subsequently, Newton and Paul (55) demonstrated a relationship between the free energy of hydration of glass and its durability. For the purpose of calculation, the glass is considered to be a physical mixture of orthosilicates (i.e., $\mathrm{Na}_{2} \mathrm{O}-\mathrm{SiO}_{2}, \mathrm{MgO}-\mathrm{SiO}_{2}$, etc.) and uncombined oxides. The free energy of hydration for the glass, $R$, can then be determined by multiplying the mole fraction of each silicate in the glass times its free energy of hydration and summing. The more negative the $R$ value, the less durable the glass is.

Plodinec et al. (56) applied this concept to a number of natural and synthetic glasses, including simulated radwaste glasses, and found a linear relationship between log normalized mass loss $\left(\mathrm{g} / \mathrm{m}^{2}\right)$ and free energy of hydration (kcal/mol) (see Fig. 9). The thermodynamic approach suggests that SRP waste glass should be as stable towards aqueous attack as natural basalt. This conclusion is consistent with studies by the authors of the static $90^{\circ} \mathrm{C}$ leaching of STRIPA granite using a MCC-1 test which yields leach rates for granite comparable to nuclear waste glass ABS 41 .

Although the thermodynamic approach appears to be useful in predicting relative durabilities of glasses, its potential has probably not been fully devleoped. Efforts are underway to determine the relationship 


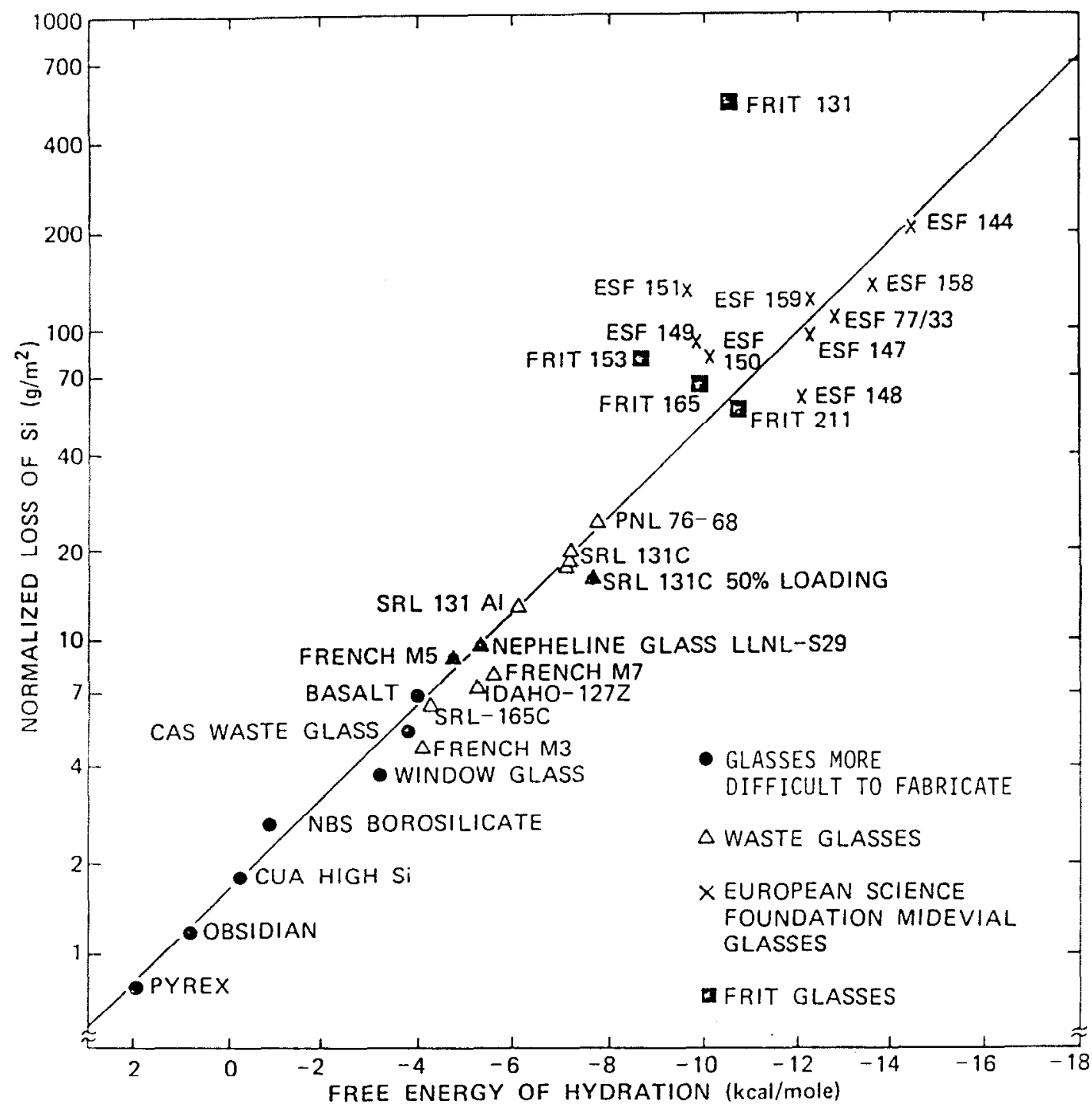

FIGURE 9. Release of structural silicon as a function of glass hydration energy (reference 56).

between the rate of glass corrosion in aqueous phases and the equilibrium constant for thermodynamic stability at the interface. Moreover, the use of thermodynamics for predicting surface film formation and stability is also being investigated. The thermodynamic approach should complement the traditional mechanistic and kinetic approaches and eventually permit the development of a unified theory of glass corrosion based on thermodynamics, mechanisms, kinetics, and surface film formation.

\section{Radiation, Thermal, and Mechanical Stability of Nuclear Waste Glasses}

It has been shown that there is no significant effect by either alpha or gamma rays on the leaching or other properties of borosilicate glasses containing actual SRP waste $(18,57,58)$. Marcoule studies of the leaching of $\sim 2-\mathrm{kg}$ blocks of five selected borosilicate glasses containing $12.2 \%$ to $14.9 \%$ LWR oxides using daily replacement dynamic leaching at $23{ }^{\circ} \mathrm{C}$ show leach rates in the range of $10^{-6}$ to $10^{-8} \mathrm{~g} / \mathrm{m}^{2}$. day for $\mathrm{Cs}^{137}, \mathrm{Sr}^{89+90}, \mathrm{Ru}+\mathrm{Rh}^{106}, \mathrm{Ce}+\mathrm{Pr}^{144}$, and $\mathrm{Sb}^{125}$ after 60 days (15). Recent data also show that radiolysis of the leachant from a borosilicate glass using ${ }^{60} \mathrm{Co}$ gamma radiation, ${ }^{244} \mathrm{Cm}$ alpha radiation, and ${ }^{90} \mathrm{Sr}$ beta radiation also produces little change in leach rates (59) under anoxic repository conditions, although studies show an effect may be present under oxidative conditions due to formation of $\mathrm{HNO}_{3}(60)$.

Data from an international collaboration (Japan, Sweden, Switzerland) evaluating the leach resistance of a radioactive glass melted at Marcoule, using the AVM process, are especially encouraging (61). The glass composition (ABS118, simulated, and JSS-A, radioactive) is close to that selected by COGEMA for commercial waste vitrification (15). The 2-L glass blocks contain $12 \mathrm{w} / \mathrm{o}$ fission product oxides and 0.2 $w / o$ plutonium oxide resulting in a total radioactivity 
per block of $1.1 \times 10^{13} \mathrm{~Bq}$. The calculated radioactivity per leach specimen is $4 \times 10^{9} \mathrm{~Bq}$. After 28 days, $90^{\circ} \mathrm{C} \mathrm{MCC}-1$, static leaching in D.I. water and an $\mathrm{Ar}$ atmosphere, both radioactive and simulated glass showed leach rates of $0.24 \mathrm{~g} / \mathrm{m}^{2} \cdot$ day. There were no apparent effects on leach rate due to the high radioactivity (61).

Cumulative doses of more than $4 \times 10^{18}$ alpha decays $/ \mathrm{cm}^{3}$ produce less than $0.1 \%$ change in density for the PNL 76-68 reference borosilicate glass and a range of $\pm 0.9 \%$ for 11 various U.S. and European glasses $(40,62)$. A review by Weber (63) compares the effect of cumulative radiation exposure of glasses to polycrystalline waste forms (Fig. 10).

Extensive data of actinide-doped glasses in both U.S. and Europe show only small effects of the radiation on leaching over a leachant temperature range from 23 to $170^{\circ} \mathrm{C}(64)$. The wide range of compositions investigated in these studies and the large variations in dose levels and types of radiation yield considerable confidence that the behavior of glass waste forms are generally insensitive to both composition and radiation.
Thermal stability of nuclear waste glasses is a potential concern if uncontrolled devitrification should occur either during processing or long-term storage. However, time-temperature-transformation (T-T-T) diagrams (such as summarized in Fig. 11) produced by Turcotte and Wald (65), Malow et al. (64), and CEA studies of devitrification temperature ranges (15) show that borosilicate nuclear waste glasses can withstand ambient air cooling after casting or even hundreds of years at temperatures of $500^{\circ} \mathrm{C}$ and below without significant devitrification occurring. Even if devitrification were to occur, Ross et al. (66) have shown that leach rates will increase by only a factor of 3 to 5 . Thus thermal stability of borosilicate glasses, even in the size of the monolithic canisters being considered, appears to be a positive attribute of this waste form.

Cracking of glass monoliths is widely recognized to increase the relative surface area, which in turn may increase the extent of leaching. Ross (66) reports the increase to be as little as $2 \times$ to $4 \times$ for annealed or slow-cooled canisters, to as much as $12 \times$ for canisters cooled by free air convection. The French

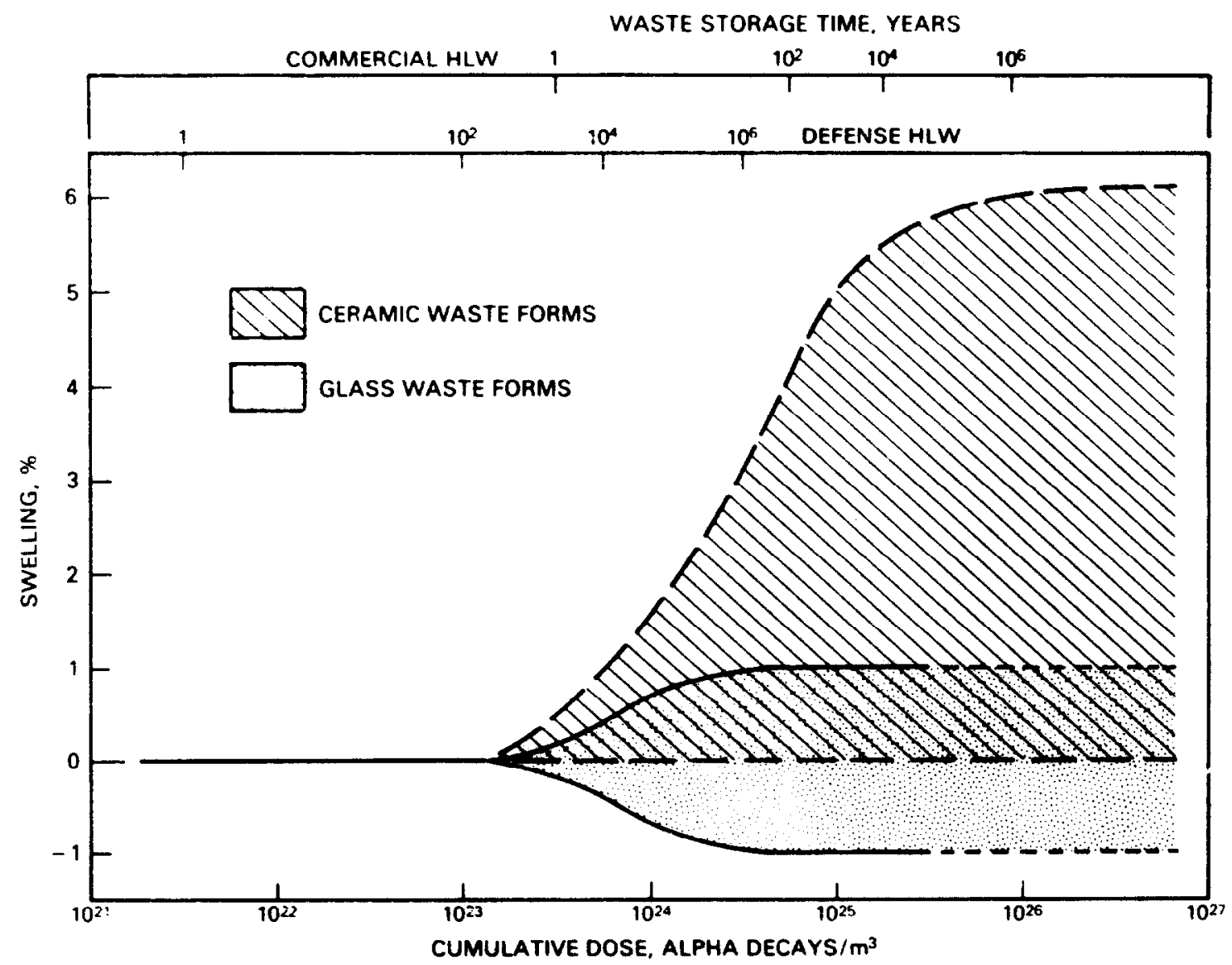

FIGURE 10. Expected volume changes as a function of dose and correlated to the waste storage times of both defense and commercial HLW forms (reference 63). 


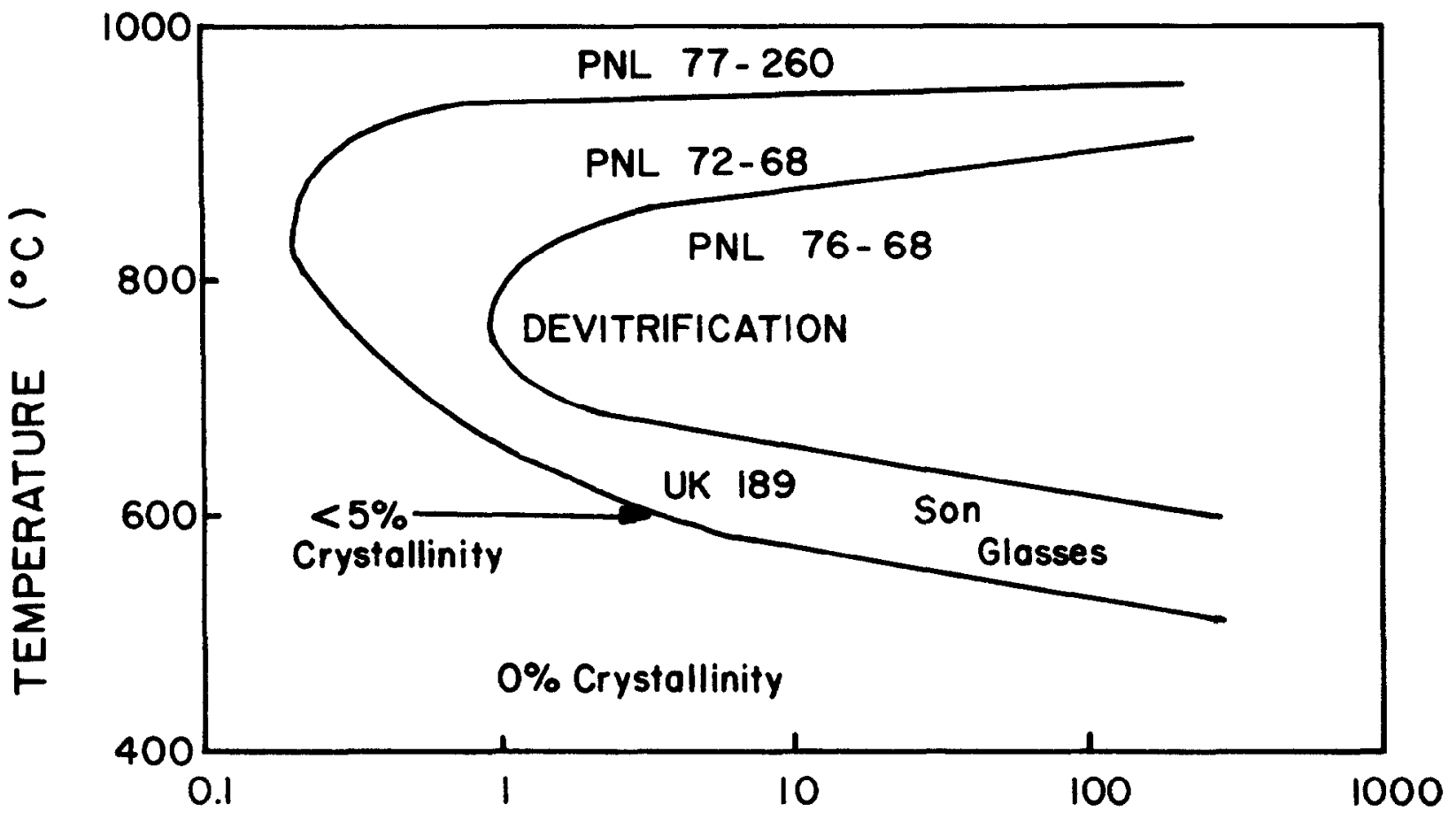

\section{TIME (days)}

FIGURE 11. T-T-T diagram for several glasses illustrating heat treatments conducive to devitrification (references 15,64 , and 65 ).

program at Marcoule reports equivalent values for effective increase in surface area (15). Similar results have been obtained by Martin, who found that the maximum increase in surface area due to cracking during cooling was $6 \mathrm{~cm}^{2} / \mathrm{cm}^{3}$. The increase in surface area caused by impact is a function of the impact velocity and is in the range of $10 \times$ for severe accident scenarios, equivalent to other waste forms (42).

For reviews on a wide range of materials properties of nuclear waste forms, such as density, thermal conductivity, thermal expansion, impact resistance, static strength, and vaporization, the reader is referred to the Battelle Laboratory report (42).

\section{POLYPHASE CERAMIC WASTE FORMS}

As far back as the early 1950s (67), it was suggested that high level radioactive wastes could be immobilized in a polyphase ceramic waste form. The use of ceramic materials largely depends upon the ability of the crystalline phases to accept a broad spectrum of chemical species within their lattices. Despite the chemical complexity of high level nuclear waste, a number of ceramic waste forms have been proposed which fulfill the above criteria with a relatively small number (compared to the number of components) of crystalline phases (see, for example Refs. 68-82). This is accomplished by choosing an assemblage of phases that are mutually compatible and show wide ranges of solid solution with respect to waste stream constituents. The large number of chemical components versus the number of phases afford a correspondingly large number of degrees of freedom during processing and densification.

Among the many potential advantages of ceramic waste forms, four are most notable:

1. inherently low leach rates for many crystalline phases (particularly titanates and phosphates);

2 . demonstrated long-term resistance to leaching and radiation damage (via natural mineral analogues);

3. ability to incorporate large volumes of waste types (i.e., high waste loading); and

4. excellent thermal and mechanical stability.

These advantages in physical and chemical properties are desirable, but do require added processing complexity for many ceramic waste form candidates.

In this section, we briefly review the composition, processing method and product properties of the reference ceramic waste form candidate for the immobilization of SRP defense wastes, Synroc-D.

\section{SYNROC-D Ceramic Waste Form}

Synroc (synthetic rock) is a titanate-based ceramic waste form proposed by Ringwood and co-workers $(68,73,74)$ for the solidification of commercial 
wastes. The major crystalline phases present in the Synroc-type waste forms are shown in Fig. 12.

The Synroc composition originally proposed by Ringwood was designed for storage of commercial reactor wastes. This material was called Synroc-C (C for commercial). A modification of this original waste form was developed for storage of high-level defense wastes similar to those in storage at the Savannah River Plant (SRP) near Aiken, SC. This waste form composition was designated as Synroc-D (D meaning defense).

There are two major phase composition differences between Synroc-C and Syroc-D. First, two additional inert (i.e., contain no radionuclides) spinel phases (Fig. 12) are formed from the large quantities of aluminum and transition metals (mainly $\mathrm{Fe}, \mathrm{Ni}$, and $\mathrm{Mn}$ ) in the defense waste (83). Second, due to the presence of $\mathrm{Na}$ and $\mathrm{Si}$ in much of the defense waste, a silicate phase (nepheline) is used as a Cs host. (For comparison, in Synroc-C a titanate phase, i.e., hollandite, is the Cs host.) In addition to the major phases, the Synroc-D type ceramics can contain various minor crystalline phases $(79,83)$ as well as a $\mathrm{Ni}, \mathrm{Fe}$ alloy and intergranular amorphous material

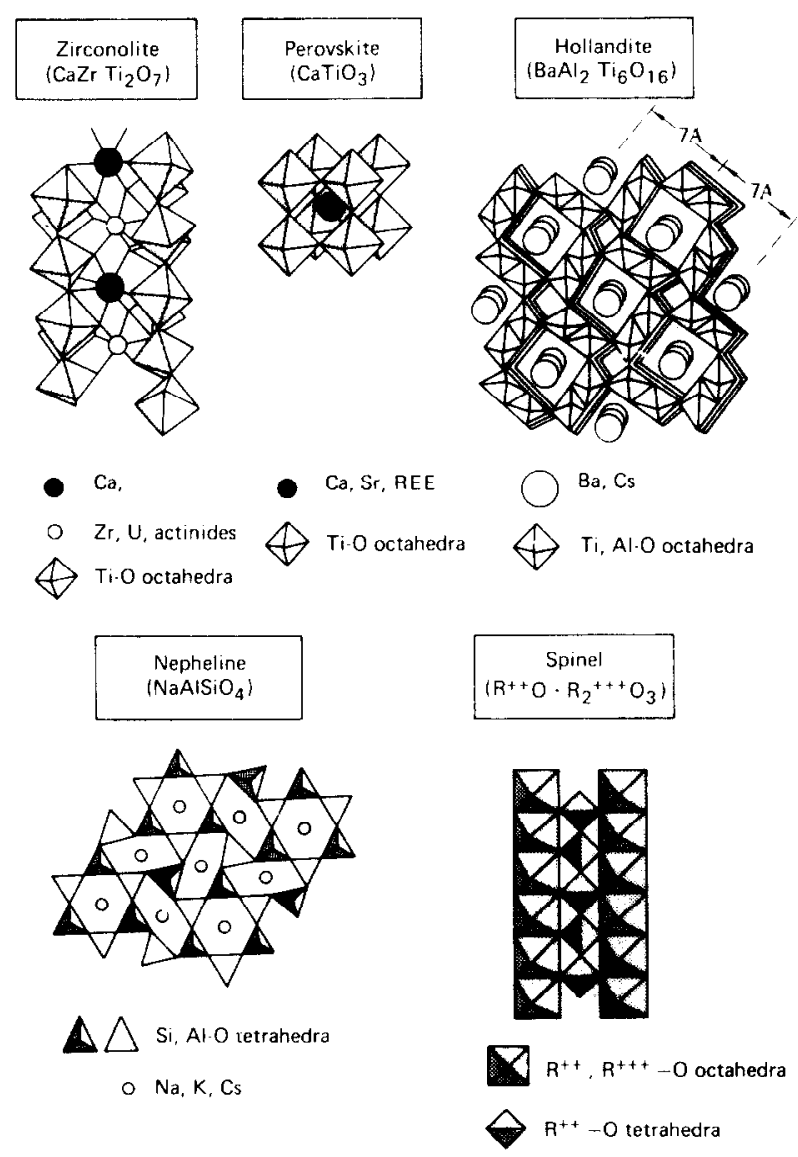

FIGURE 12. Structures of the crystalline phases in Synroc. Synroc-C is comprised of zirconolite, perovskite, and hollandite. Synroc-D is composed of zirconolite, perovskite, nepheline, and spinel.
$(81,82)$. The relative proportion of the various phases is a function of the waste composition and processing conditions. The availability of a variety of highly stable Al-, Fe-, and Ti-based crystalline phases to the Synroc-D assemblage improves its flexibility and tolerance to process variations.

In regard to formulation, it is important to realize that only four additives $\left(\mathrm{TiO}_{2}, \mathrm{ZrO}_{2}, \mathrm{CaO}\right.$, and $\left.\mathrm{SiO}_{2}\right)$ are used in the preparation of Synroc containing defense waste (see Table 3 and Fig. 13). Further, it has been reported that components in the waste sludge feed can vary by as much as $\pm 50 \%$ in composition without affecting either the quantity of Synroc additives needed or the quality of the final product. This experience shows the Synroc formulation is tolerant of wide variations in feed composition and thus forgiving of potential feed stream upsets.

A series of papers have addressed the formulation, lab scale preparation $(75,84)$, phase characterization (83), performance testing $(69,79,84,85)$, and pilot scale processing $(76,86-90)$ of Synroc containing simulated SRP defense waste. Several economic analyses of the ceramic consolidation process have also been published $(22,91)$. Furthermore, work is being performed at the Rockwell International Science Center aimed at improving the Synroc-D formulation for SRP wastes and developing ceramic formulations and processes for other U.S. wastes; these programs include Rockwell Hanford Operation (76), ICPP (77), Barnwell (78), and NFS (78) waste.

\section{Synroc-D Processing}

The Synroc-D ceramic process, at the present state (four yrs R\&D) is less developed than the more

TABLE 3

Nominal Oxide Composition of Synroc D (Sample S29) Containing Simulated SRP Composite Sludge

\begin{tabular}{lccc}
\hline $\begin{array}{c}\text { Component } \\
\text { Oxide }\end{array}$ & $\begin{array}{c}\text { SRP Composite } \\
\text { Sludge Composition }\end{array}$ & $\begin{array}{c}\text { Synroc } \\
\text { Additives }\end{array}$ & Total \\
\hline & $w t \%$ & $w t \%$ & $w t \%$ \\
$\mathrm{Fe}_{2} \mathrm{O}_{3}$ & 23.8 & - & 23.8 \\
$\mathrm{Al}_{2} \mathrm{O}_{3}$ & 18.6 & - & 18.6 \\
$\mathrm{MnO}_{2}$ & 7.4 & - & 7.4 \\
$\mathrm{U}_{3} \mathrm{O}_{3}$ & 2.1 & - & 2.1 \\
$\mathrm{CaO}$ & 1.8 & 5.3 & 7.1 \\
$\mathrm{NiO}$ & 3.0 & - & 3.0 \\
$\mathrm{SiO}$ & 0.6 & 6.6 & 7.2 \\
$\mathrm{Na}_{2} \mathrm{O}$ & 3.3 & - & 3.3 \\
$\mathrm{Na}_{2} \mathrm{SO}_{4}$ & 0.6 & - & 0.6 \\
$\mathrm{Cs}_{2} \mathrm{O}$ & 0.25 & - & 0.25 \\
$\mathrm{SrO}$ & 0.25 & - & 0.25 \\
$\mathrm{Ce}_{2} \mathrm{O}_{3}$ & 0.50 & - & 0.50 \\
$\mathrm{Nd}_{2} \mathrm{O}_{3}$ & 0.50 & - & 0.50 \\
$\mathrm{TiO}_{2}$ & - & 6.6 & 6.6 \\
$\mathrm{ZrO}_{2}$ & - & 37.3 & 100.00 \\
$\mathrm{Total} \mathrm{Wt} \%^{2}$ & 62.7 & & \\
\hline
\end{tabular}



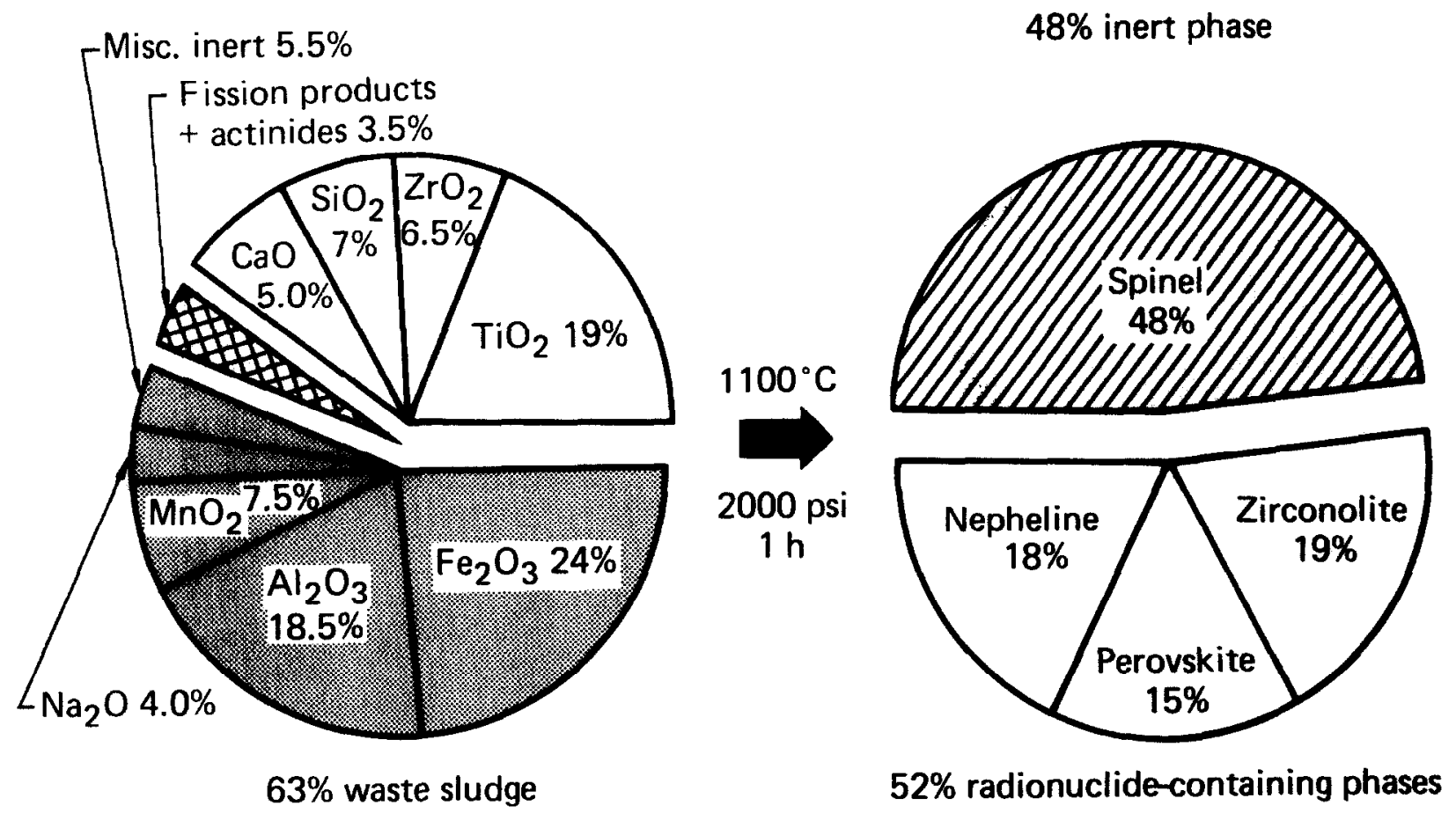

FIGURE 13. Nominal composition of Synroc-D starting materials and final phase assemblage.

mature (greater than $15 \mathrm{yr}$ ) borosilicate glass process. This is expected. Synroc is a new waste form and nearly all research has been directed toward laboratory synthesis and testing of the product. However, as a result of engineering $R \& D$, significant simplification in Synroc-D processing has occurred $(86,87)$. In the initial Synroc preparation scheme (Fig. 14), the additives were blended and sometimes milled with the waste slurry. After spray drying, this mixture was calcined and then chemically reduced in two separate batch operations. Often the powder was reground prior to hot pressing. The initial capacity was only about $50 \mathrm{~g} /$ day.

In the present preparation procedure, all grinding operations have been eliminated. The waste and additives are simply blended in a large tank using a pro-

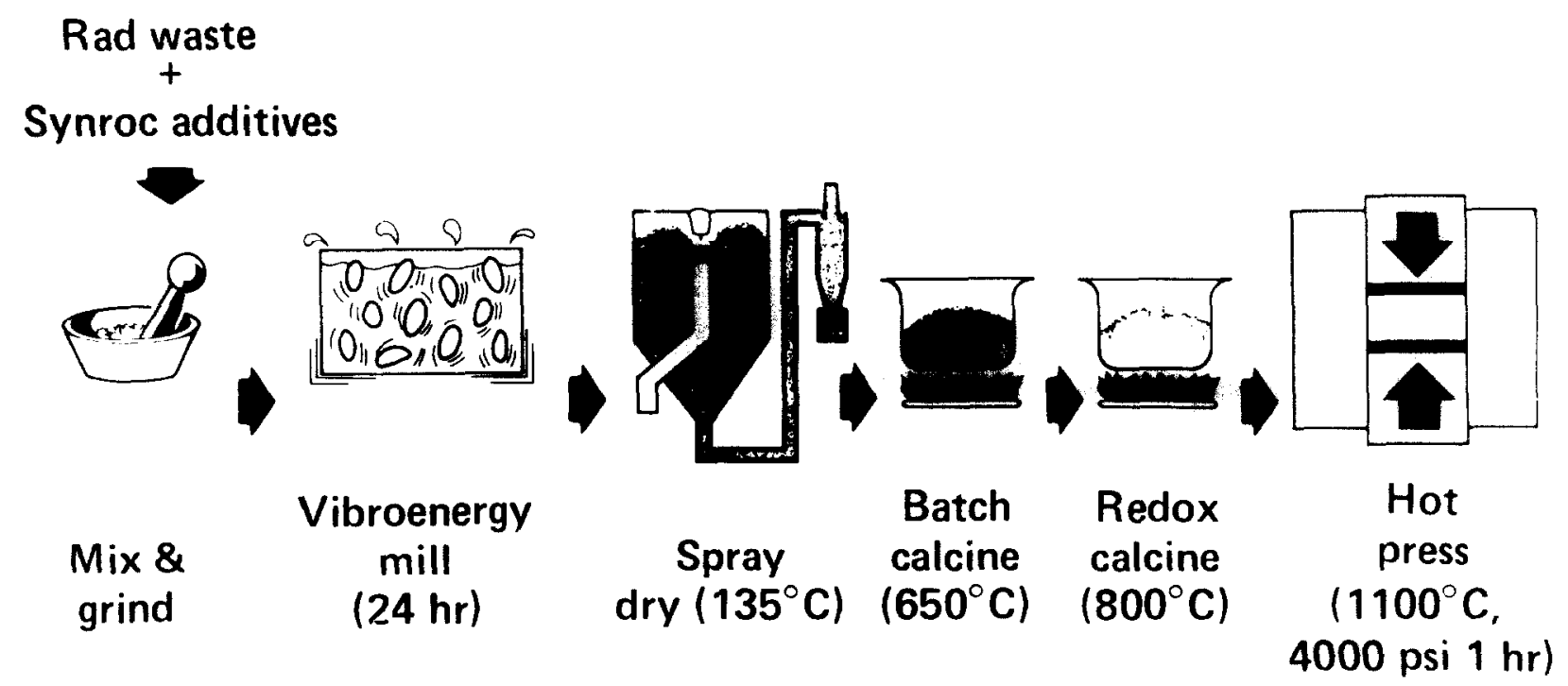

FIGURE 14. Schematic diagram of the initial laboratory procedure used to prepare Synroc-D. 
peller mixer. The spray dryer and batch calciner steps have been replaced by a slurry-fed, fluidized bed calciner (Fig. 15). This pilot-scale unit has a powder production capacity of up to $100 \mathrm{~kg} /$ day. In the area of densification, single monoliths of Synroc-D weighing as much as $50 \mathrm{~kg}(110 \mathrm{lb})$ have been prepared using conventional hot-isostatic-pressing (HIP) (89). Using current HIP technology, two Synroc monoliths, containing $500 \mathrm{~kg}$ of waste each, could be prepared daily using a single HIP unit.

\section{Properties of Synroc-D}

Waste Loading. Waste loadings of between $60-65$ $\mathrm{wt} \%$ have been achieved for Synroc-D containing SRP composite waste sludge. This corresponds to a waste loading (as volumetric concentration) of $2.3-2.5 \mathrm{~g} / \mathrm{cm}^{3}$ and an equivalent Curie content of about $1.0 \mathrm{Ci} / \mathrm{cm}^{3}$.

Mechanical and Thermalphysical Properties. Rather extensive physical property measurements have been carried out on Synroc-D $(69,85)$. Table 4 summarizes some of the data for several key properties. In general, the results are typical for many ceramic materials.

The flexural and compressive testing were done according to ASTM specifications, with samples having a length-to-diameter ratio greater than five. The elastic moduli were determined using the pulseoverlap ultrasonic method developed by Papadakis (92). Sample sizes of $1.3 \times 1.3 \times 0.4 \mathrm{~cm}$ were used, and the frequencies were in the $5-20 \mathrm{MHz}$ range.

Constant energy density $\left(10 / \mathrm{cm}^{3}\right)$ impact friability tests carried out by Jardine (93) showed that Synroc-D produced less than $0.16 \mathrm{wt} \%$ "respirable fines" (i.e., particles less than $10 \mu \mathrm{m}$ in diameter).

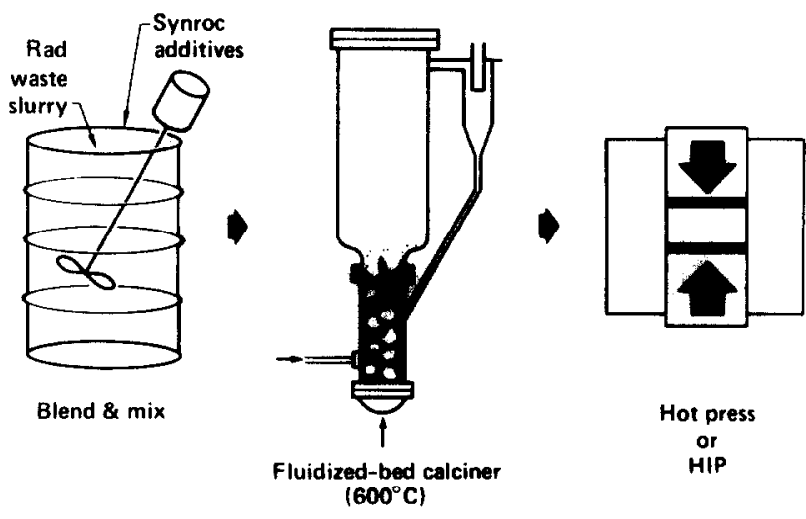

FIGURE 15. Schematic representation of the three major unit operations currently used to prepare Synroc-D on a small pilotplant scale.
TABLE 4

\begin{tabular}{|c|c|}
\hline Property & Synroc-D Composite \\
\hline \multicolumn{2}{|l|}{ Mechanical } \\
\hline Flexural Strength (psi) ${ }^{\mathrm{a}}$ & $9.4 \times 10^{3}$ \\
\hline Compressive Strength (psi) & $5.1 \times 10^{4}$ \\
\hline \multicolumn{2}{|l|}{ Elastic Constants: } \\
\hline Bulk Modulus (psi) & $15.6 \times 10^{6}$ \\
\hline Shear Modulus (psi) & $7.8 \times 10^{6}$ \\
\hline Youngs Modulus (psi) & $20.1 \times 10^{6}$ \\
\hline Poisson's Ratio & 0.284 \\
\hline \multicolumn{2}{|l|}{ Microhardness $\left(\mathrm{kg} / \mathrm{mm}^{2}\right)^{b}$} \\
\hline $\mathrm{HKN}_{50}$ & 947 \\
\hline $\mathrm{HKN}_{100}$ & 868 \\
\hline $\mathrm{HKN}_{300}$ & 695 \\
\hline Density $\left(\mathrm{g} / \mathrm{cm}^{3}\right)$ & 4.00 \\
\hline \multicolumn{2}{|l|}{ Thermal physical } \\
\hline $\begin{array}{l}\text { Thermal conductivity } \\
\left(\mathrm{W} / \mathrm{m}-\mathrm{K} \text { at } 22^{\circ} \mathrm{C}\right)\end{array}$ & 1.9 \\
\hline $\begin{array}{l}\text { Thermal expansion coeff } \\
\left(22-950^{\circ} \mathrm{C}\right)\end{array}$ & $11 \times 10^{-6}$ \\
\hline
\end{tabular}

aModulus of rupture (4 point loading, $2.5-\mathrm{cm}$ span).

bKnoop hardness measured using a Leitz Durimet instrument.

Leach Test Results. A number of different leach tests have been used to evaluate Synroc-D. Due to the space limitations in this paper, only data from MCC-1 (static, $90^{\circ} \mathrm{C}$ ) and $\mathrm{MCC}-2$ (static, $150^{\circ} \mathrm{C}$ ) tests will be presented. These tests were carried out on monolithic samples.

The average leach rates (Table 5 and 6) were computed by the method outlined in the MCC-1 test (23) and are usually referred to as the "Normalized Elemental Leach Rate" $\left(L R_{i}\right)$ :

$$
L R_{i}=N L_{i} / t=m_{i} /(f i, S A, t),
$$

where $N L_{i}$ is the normalized elemental mass loss based on element $i\left(\mathrm{~g} / \mathrm{m}_{2}\right) ; m_{i}$ is the mass of element $i$ in the solution $(\mathrm{g}) ; S A$ is the geometric surface area $\left(\mathrm{m}^{2}\right)$; and $f_{i}$ is the mass fraction of element $i$ in the sample. In this calculation, $t$ is total duration of the leaching experiments (days); thus it is important to note that $L R_{i}$ represents an average over this time.

Of the elements tested for, the actinides (represented here by $U$ ) had the lowest measured leach rates. This is due to the excellent durability of zirconolite. The relatively greater Cs leachability is due to the fact that it has been immobilized in a silicate phase (nepheline) and that some Cs is usually present in the intergranular amorphous phase $(81,82)$. In contrast, Cs has a leach rate several orders of magnitude lower when immobilized in the titanate phase, hollandite, as in Synroc-C.

In summary, the most durable phase in Synroc-D is zirconolite, followed by the spinels, perovskite and, finally, the least durable crystalline phase, nepheline. 
TABLE 5

Normalized Elemental Leach Rate (LR, $g / \mathbf{m}^{2} \cdot$ day) via MCC-1 Leach Test ( $90^{\circ} \mathrm{C}$, Monoliths) for Synroc-D Containing Simulated SRP Composite Sludge (S29)

\begin{tabular}{|c|c|c|c|c|c|c|}
\hline \multicolumn{4}{|c|}{ Deionized Water } & \multirow{2}{*}{$\frac{\text { Silicate Water }}{28 \mathrm{~d}}$} & \multirow[b]{2}{*}{$28 \mathrm{~d}$} & \multirow{2}{*}{$\frac{\text { Brine }}{28 \mathrm{~d}}$} \\
\hline Element & $3 d$ & $7 \mathrm{~d}$ & $14 \mathrm{~d}$ & & & \\
\hline $\mathrm{Al}$ & 0.81 & 0.50 & 0.31 & 0.18 & 0.070 & 0.0046 \\
\hline $\mathrm{Fe}$ & 0.007 & 0.0043 & 0.00086 & $3.4 \times 10^{-4}$ & $4.3 \times 10^{-4}$ & - \\
\hline $\mathrm{Mn}$ & 0.087 & 0.057 & 0.029 & 0.022 & 0.0020 & - \\
\hline $\mathrm{Ni}$ & -- & 0.048 & 0.057 & 0.043 & 0.0074 & - \\
\hline $\mathrm{Si}$ & 2.50 & 1.89 & 1.06 & 0.67 & 0.24 & 0.282 \\
\hline $\mathrm{Sr}$ & 1.40 & 0.92 & 0.60 & 0.38 & 0.010 & $<0.1$ \\
\hline $\mathrm{Ca}$ & 1.05 & 0.59 & 0.34 & 0.21 & 0.083 & - \\
\hline $\mathrm{Na}$ & 2.97 & 1.47 & 0.94 & 0.62 & 0.33 & - \\
\hline Cs & 3.67 & 1.57 & 1.71 & 0.79 & 0.54 & 0.45 \\
\hline $\mathrm{Ti}$ & $<7.6 \times 10^{-4}$ & $<3.3 \times 10^{-4}$ & $<1.6 \times 10^{-4}$ & $<8 \times 10^{-5}$ & $<8 \times 10^{-5}$ & $<0.0019$ \\
\hline $\mathrm{Zr}$ & $<0.0032$ & $<0.0014$ & $<0.0007$ & $<0.0004$ & $<0.0004$ & $<0.0079$ \\
\hline $\mathrm{U}$ & - & $2.8 \times 10^{-4}$ & $1.4 \times 10^{-4}$ & $1.1 \times 10^{-4}$ & - & - \\
\hline $\mathrm{Ce}$ & $<1.03$ & $<0.44$ & $<0.22$ & $<0.11$ & - & - \\
\hline Nd & $<0.077$ & $<0.033$ & $<0.016$ & $<0.008$ & - & - \\
\hline Mass loss $\left(g / \mathrm{m}^{2} \cdot\right.$ day $)$ & 0.62 & 0.28 & 0.21 & 0.13 & 0.043 & 0.031 \\
\hline pH & 6.0 & 6.0 & 6.1 & 6.5 & 8.0 & 6.2 \\
\hline$\Delta \mathrm{pH}$ & 0.2 & +0.2 & +0.3 & +0.7 & +0.7 & 0.0 \\
\hline
\end{tabular}

Current Status of Ceramic Waste Form Development With the recent selection of glass as the final waste form for SRP U.S. defense wastes, DOE-sponsored work on the ceramic alternate was discontinued effective January 1983. Furthermore, there is presently no formal U.S. program for the development of a ceramic for future commercial LWR wastes. However, significant efforts on developing ceramic forms and processes for both defense and commercial highlevel wastes are continuing at the Rockwell International Science Center (75-77), as well as in Australia and Great Britain.

\section{WASTE FORM-STORAGE SYSTEM INTERACTIONS}

The ultimate reliability of any nuclear waste form will depend upon the rates of interaction of repository groundwaters with the externally accessible surfaces of the waste form and other materials in the storage system. The number of interfaces involved in storage systems is large, as is the potential range of temperatures, flow rates or residence times, and groundwater chemistries. However, most data acquired to date, upon which one can base predictions of leaching

TABLE 6

MCC-2 Static Leach Test Results on Synroc-D Containing Composite Sludge

\begin{tabular}{lccc}
\hline & \multicolumn{3}{c}{ Normalized Elemental Leach Rate (LR), $\mathrm{g} / \mathrm{m}^{2} \cdot$ day } \\
\cline { 2 - 4 } \cline { 2 - 4 } Element & Deionized Water & Silicate Water & Brine \\
\hline $\mathrm{Al}$ & 0.48 & 0.194 & 0.001 \\
$\mathrm{Fe}$ & 0.0057 & 0.005 & 0.2 \\
$\mathrm{Mn}$ & 0.034 & 0.005 & 0.43 \\
$\mathrm{Ni}$ & 0.040 & 0.27 & 1.89 \\
$\mathrm{Si}$ & 2.87 & 0.95 & 2.68 \\
$\mathrm{Sr}$ & 1.82 & 0.49 & 1.53 \\
$\mathrm{Ca}$ & 0.63 & 0.19 & 0.52 \\
$\mathrm{Na}$ & 1.99 & 0.081 & - \\
$\mathrm{Cs}$ & 2.53 & 0.74 & 1.96 \\
$\mathrm{Ti}$ & $<8.0 \times 10^{-5}$ & $<8.0 \times 10^{-5}$ & 0.0019 \\
$\mathrm{Zr}$ & $<4.0 \times 10^{-4}$ & $<4.0 \times 10^{-4}$ & 0.0079 \\
$\mathrm{U}$ & $9 \times 10^{-4}$ & $<0.017$ & - \\
$\mathrm{Mass}$ loss $\left(\mathrm{g} / \mathrm{m}^{2}\right.$-day) & 0.46 & 0.13 & 0.23 \\
$\mathrm{pH}$ & - & 7.0 & 6.2 \\
$\Delta \mathrm{pH}$ & - & 0.0 & 0.0 \\
\hline
\end{tabular}


mechanisms and rates, involve simple static or flow experiments using D.I. $\mathrm{H}_{2} \mathrm{O}$ in contact with small samples or powders. Work is now underway to expand these simplified leaching studies, to include simulations of the interfacial interactions that will be present in a repository. However, a difficulty in designing laboratory studies to simulate repository conditions is the wide range of potential geologic sites under consideration for repositories. The alternatives being considered worldwide include (in probable order of importance): salt, granite, basalt, tuff, clay, diabase, slate, and granodiarite. The chemistry and percent of water in the rocks, $\mathrm{pH}$, Eh, temperature, and flow rates are different for each rock type and often vary from site to site for a given type of rock.

A recent analysis (94) of the range of variables for salt, basalt, tuff, and granite repositories indicates that at least four test solutions are required to represent the range of water chemistries found in repositories. The MCC brine and silicate water test solutions already in use (23) are suitable for two test conditions. However, at least one additional saline and another silicate solution need to be used in lab studies of waste form-system interactions in order to generalize test results to a range of repositories.

For nearly all repositories it is probable that water will eventually come into contact with wasteforms containing HLW. As mentioned above, although flow rates of several hundred $\mathrm{L} / \mathrm{yr}$ have been reported for some potential repository types, it is most likely that flow rates will be only a few liters/year (94). At the wasteform-water interface, especially within cracks, static conditions will usually exist. Consequently, in order to evaluate potential wasteform-repository interactions, it is necessary to conduct both static and flow experiments varying $S A / V$ (surface area/solution volume), cell volume, flow rate, temperature, and time. MCC- 1 and MCC-4 tests are designed to test static and flow conditions, respectively.

Although a number of studies of waste form-rock interactions have been conducted over the years (see Table 7), only a few generalizations can be made at this time. Brine solutions generally decrease the rate of glass corrosion $(47,95,96)$, with the possible exception of $\mathrm{Sr}$ and $\mathrm{Ce}(51)$. In the brine solutions, a protective magnesium chloride complex forms on the glass surface. Compacted bentonite (36) and clay (97) increase the rate of glass corrosion considerably. The presence of granite (98) can lead to a small increase or decrease depending upon $S A / V$ (see Figs. 16 and 17). These effects are due to an enhanced rate of ion exchange between the glass, the silicate surfaces, and $\mathrm{Ca}$ containing solutions. Exposure of nuclear waste glass to tuffs result in a small decrease in corrosion rate, perhaps due to a buffering effect (47). Auto- clave tests of basalt-glass interactions (99) and granodiorite-glass (100) interactions show a decreasing rate of attack.

The most extensive of the field tests (Table 7) involves deep burial ( $345 \mathrm{~m}$ below surface) in granite in the STRIPA mine in Sweden $(36-38,48,49,98)$. Two configurations of samples are used. One is a $32-\mathrm{mm}$ diam. $\times 35-\mathrm{mm}$ length minican where an alkali borosilicate glass with simulated HLW is cast into stainless steel, and 8 glass-steel-glass, glass-glass, and glass-bentonite interfaces are analyzed. The second configuration is the so-called 51-mm diam $\times 5-\mathrm{mm}$ thick "pineapple slices," which result in 28 interfaces including glass-glass, glass-bentonite, glass-granite, glass- $\mathrm{Cu}$, glass- $\mathrm{Ti}$, glass- $\mathrm{Pb}$, and glass- $\mathrm{Pb} / \mathrm{Ti}$.

Five different glass compositions are under test, two from the SKBF/Project KBS-UF program, with 9.0\% simulated Swedish commercial waste and three from the SRL-UF-SKBF/KBS program with 29.8 to $35 \%$ simulated U.S. defense waste. A $20-\mathrm{mm}$ center hole is provided in the samples to accommodate a heater rod, and the tests are conducted at $90^{\circ} \mathrm{C}$ and ambient $\left(8-10^{\circ} \mathrm{C}\right)$ mine temperatures. Flow rates through similar holes elsewhere in the mine were approximately $1 \mathrm{~L} / \mathrm{yr}$. After removal from burial the samples are analyzed with Fourier transform infrared reflection spectroscopy (FTIRRS), secondary ion mass spectroscopy (SIMS), Rutherford backscattering, and optical microscopy. Solution ion analysis is

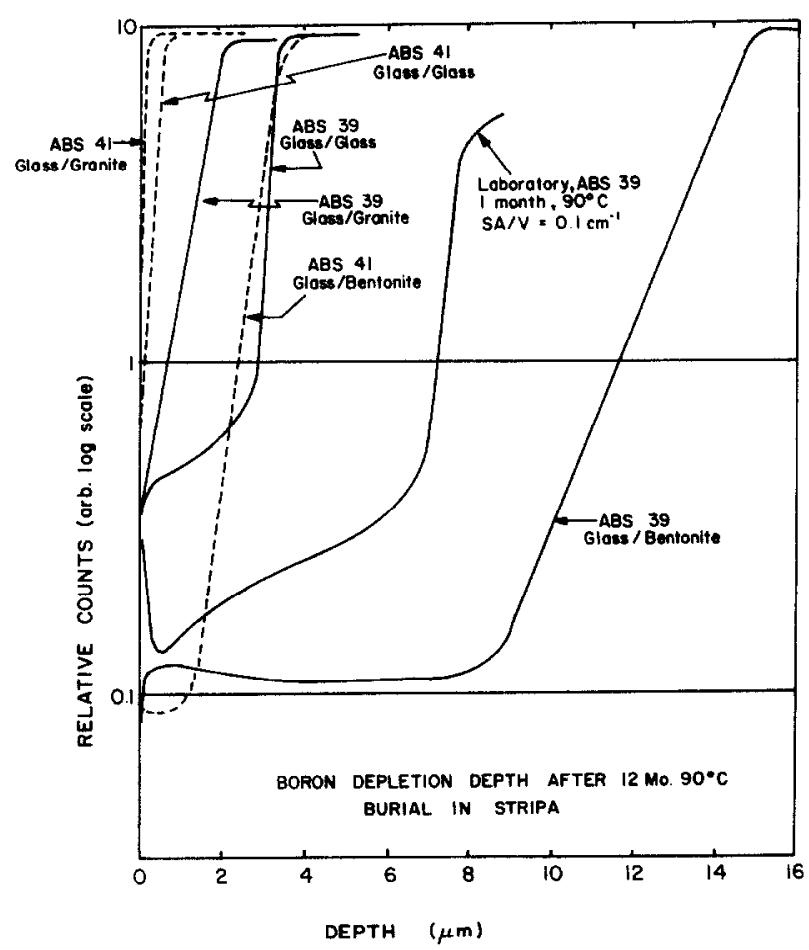

FIGURE 16. Depth compositional profile of Boron obtained by SIMS on glasses exposed to several environments. Data courtesy of Professor Alexander Lodding, Chalmers Institute, Sweden. 
TABLE 7

Waste Form/Rock Interactions (Laboratory and Field)

\begin{tabular}{|c|c|c|c|c|c|c|}
\hline Waste Form & Rock & Conditions & Authors & Year & Ref. & Rock Effect \\
\hline $\begin{array}{l}\text { Glass Ceramic } \\
\text { Spent Fuel }\end{array}$ & Shale & $\begin{array}{l}100-400^{\circ} \mathrm{C} \\
30 \mathrm{MPa}\end{array}$ & Freeborn et al. & 1982 & 105 & \\
\hline $\begin{array}{l}76-68 \\
\text { Minican }\end{array}$ & $\begin{array}{l}\text { Basalt } \\
\text { Granite }\end{array}$ & $\begin{array}{l}250^{\circ} \mathrm{C} \\
200 \mathrm{psi}\end{array}$ & Bradley et al. & 1981 & 106 & $\begin{array}{l}\text { Yes, esp. } \\
\text { for basalt }\end{array}$ \\
\hline $76-68$ & $\begin{array}{l}\text { Wipp } \\
\text { Brine (Soln) }\end{array}$ & $250^{\circ} \mathrm{C}$ & Chick et al. & 1979 & 107 & $\begin{array}{l}\text { Yes, element } \\
\text { dependent }\end{array}$ \\
\hline $76-68$ & Basalt, salt & $350^{\circ} \mathrm{C}$ & Westsik et al. & 1978 & 108 & Yes \\
\hline Synroc & Brine & $110^{\circ} \mathrm{C}$ & Solomah et al. & 1980 & 109 & - \\
\hline $\begin{array}{l}\text { SRL-131 } \\
+30 \% \text { TDS }\end{array}$ & $\begin{array}{l}\text { Shale, basalt, } \\
\text { Granite, tuff }\end{array}$ & $90^{\circ} \mathrm{C}$ & Wicks et al. & 1982 & 47 & $\begin{array}{l}\text { Yes, esp. } \\
\text { for salt }\end{array}$ \\
\hline U.K. 189 Glass & Granite & $60^{\circ} \mathrm{C}$ & Hall et al. & 1982 & 110 & - \\
\hline U.K. 209/M22 Glass & Granodiorite & $\begin{array}{l}100^{\circ} \mathrm{C} \\
50 \mathrm{MPa}\end{array}$ & Savage et al. & 1982 & 100 & - \\
\hline 6 Belgian Glasses & Clay & $\begin{array}{l}40^{\circ} \mathrm{C}- \\
200^{\circ} \mathrm{C}\end{array}$ & Iseghem et al. & 1982 & 97 & Yes \\
\hline Glass-Ceramic Ceramic & Granite & & Hayward et al. & 1982 & 111 & Yes 1 \\
\hline SRL 21 & $\begin{array}{l}\text { Granite, obsidian } \\
\text { basalt, chert, } \\
\text { phosphate clay }\end{array}$ & $90^{\circ} \mathrm{C}$ & Clark et al. & 1982 & $\begin{array}{l}115 \\
116\end{array}$ & - \\
\hline KBS 39 & $\begin{array}{l}\text { Brine Soln, } \\
\text { silicate Soln }\end{array}$ & $90^{\circ} \mathrm{C}$ & Hermansson et al. & 1982 & 95 & $\begin{array}{l}\text { Yes, brine I } \\
\text { Silicate I }\end{array}$ \\
\hline Glass & Chalk River Sand & Ambient & Merritt et al. & 1963 & 112 & - \\
\hline HLW Glass & Sand & Ambient $15 \mathrm{yr}$ & Merritt et al. & 1976 & 113 & - \\
\hline Glass & $\begin{array}{l}\text { Soil } \\
\text { England }\end{array}$ & $\begin{array}{l}\text { Ambient } \\
2 \mathrm{yr}, 9 \mathrm{yr}\end{array}$ & Fletcher & 1974 & 114 & - \\
\hline KBS Glass & $\begin{array}{l}\text { Granite } \\
\text { STRIPA }\end{array}$ & $\begin{array}{l}\text { Ambient } 90^{\circ} \mathrm{C} \\
1 \text { month, } 1 \text { yr }\end{array}$ & $\begin{array}{l}\text { Werme et al. } \\
\text { Hench et al. }\end{array}$ & $\begin{array}{l}1982 \\
1982\end{array}$ & $\begin{array}{l}36 \\
37 \\
48 \\
98\end{array}$ & Yes 1 \\
\hline $\begin{array}{l}\text { SRL131 + 30\%TDS } \\
\text { SRL165 + 30\%TDS }\end{array}$ & $\begin{array}{l}\text { Granite } \\
\text { STRIPA }\end{array}$ & $\begin{array}{l}\text { Ambient } \\
1 \text { month, } 2 \text { yr }\end{array}$ & Clark et al. & 1983 & 49 & \\
\hline
\end{tabular}

not possible in these burial experiments; this is the primary disadvantage of such a method.

Figures 16 and 17, which summarize some of the findings from the in-situ granite burial experiments, are based upon SIMS analyses by Lodding (Chalmers University of Technology, Sweden) and FTIRRS analyses of the glass interfaces $(36-38,48)$. As many as 15-20 elements are measured by SIMS and the resulting compositional profiles are complicated. However, the elements in the nuclear waste glasses generally can be categorized as three types: [1] mobile ions depleted from the surface without reaching solubility limits; [2] mobile ions that reach solubility limits and therefore concentrate in the surface; and [3] relatively immobile, matrix ions.

The maximum rate of release of a species from a glass surface is determined by the type [1] ions. Sodium, lithium, and boron behave as type [1] ions. Profiles of boron depletion depths of the "pineapple slice" configuration after $1 \mathrm{yr}, 90^{\circ} \mathrm{C}$ STRIPA burial are compared in Fig. 16 for various glass interfaces and two glass compositions. Both compositions (Table 2) are similar to the glasses selected by the French for use in commercial waste solidification at La Hague (15). The boron depletion profile of glass ABS 39 after just 28 days of MCC-1 static $90^{\circ} \mathrm{C}$ leaching with $S A / V=0.1 \mathrm{~cm}^{-1}$ is shown for comparison in Fig. 16.

The depletion depths shown in Fig. 17 are as low as $0.2 \mu \mathrm{m}$ after $1 \mathrm{yr}, 90^{\circ} \mathrm{C}$ burial, depending upon composition and the interface exposed. The presence of bentonite increases the depth by a factor of approximately 5 , whereas granite decreases the depletion depth by a factor of about 2 . This behavior is attributed to compacted bentonite serving as a semiinfinite ion exchange medium where $\mathrm{Ca}^{2+}$ from the bentonite is replacing $\mathrm{Na}^{+}, \mathrm{Li}^{+}$, and $\mathrm{B}^{3+}$ from the glass (33). In contrast, the small congruent solubility of granite seems to augment the glass in reaching solubility limited leaching (98).

Figure 17 summarizes the time dependence of the boron depletion depth for these experiments using 


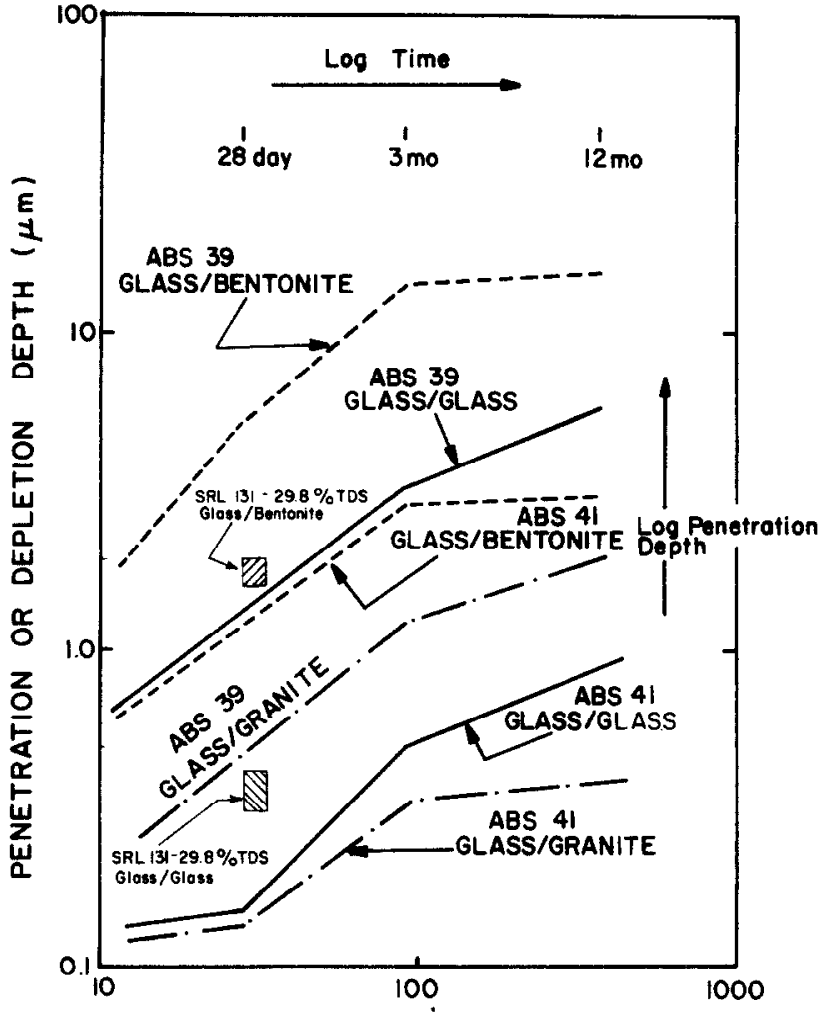

TIME (doys)

FIGURE 17. Leaching depth as a function of exposure time and environments based on the greatest depth of surface alteration as measured by SIMS. Data courtesy of Professor Alexander Lodding, Chalmers Institute, Sweden.

data from 1-, 3-, and 12-month burials. An important finding is the decreasing rate of surface depletion at longer times, equivalent to the findings of long-term laboratory leaching experiments (see Fig. 4). Consequently, one can use an extrapolation of the 3-month-12-month data to predict an upper limit for the depletion depth resulting from leaching during the thermal period. If one assumes a worst case of water contact within a breached canister throughout an entire $90^{\circ} \mathrm{C}$ thermal period (ca. $300 \mathrm{yr}$ ), it would result in alkali depletion to no more than $9 \mu \mathrm{m}$ for glass ABS 41 and no more than $70 \mu \mathrm{m}$ for glass ABS 39. The decreasing slope of the glass-bentonite interfaces (Fig. 17) indicates that the rapid bentonite ionexchange process will also reach saturation and will not degrade long-term leaching performance of the storage system over just glass-glass interfaces.

Several other points need to be considered in the use of the above extrapolation. Lower $S A / V$ ratios than those achieved in the STRIPA burial experiments might be present in an actual breached canister. A comparison of surface profiles from lab studies at $S A / V=0.1 \mathrm{~cm}^{-1}$ with 2 -yr post-burial data indicates that depletion zones may increase by a factor of
5 to 10 (Fig. 16). Recent studies of $S A / V$ dependence of leaching in the laboratory have shown that as $S A / V$ increases, the depth of surface ion depletion decreases (see Fig. 4 and Ref. 101). Consequently, significantly lower depletion depths are measured in in situ burial experiments, which replicate more closely repository conditions than the laboratory. Primarily, this is for the reasons: [1] a higher $S A / V$ ratio in the burial experiments, and [2] the presence of $\mathrm{Si}$ in natural groundwaters which reduces the amount of Si extracted from the glass before solubility limits are exceeded.

It is important to note that the burial tests of simulated SRP HLW waste glasses showed that glass SRL165 with $30 \%$ TDS waste was better than SRL131/TDS (49). It was shown also that an increase in waste loading from $30 \%$ to $35 \%$ increased the performance of SRL131/TDS glass. These findings, along with the demonstrated effects of bentonite, granite, and metal interfaces, confirm the results of lab experiments. This correlation of lab data with field data considerably increases the confidence in both.

Additional experiments are in progress to quantify these burial data in order to use post-burial depletion profiles in predictive equations. However, the presence of compacted bentonite, or other backfill or overpack materials, may control the solution chemistry such that $S A / V$ effects are altered in a repository using such components. McVay and Buckwalter (102) have investigated the effects of ductile iron on the corrosion behavior of PNL 76-68 and found a synergistic interaction between the two materials. The presence of iron enhances the glass dissolution and glass enhances iron corrosion. This results in more total elemental removal from the glass in deionized water, tuff, and basalt waters. Similar results have been found by the authors for SRL $131+29.8 \%$ TDS in deionized water.

Another factor is that use of compacted bentonite in the STRIPA burial ensures tightly adherent interfaces due to swelling pressures; therefore, it more closely simulates high $S A / V$ repository conditions than lab experiments with low $S A / V$ ratios.

On the conservative side, data from longer term 2-3-yr burial samples may result in even lower rates of surface depletion, since the slopes of Fig. 17 may continue to decrease. Progressively decreasing temperatures during the thermal period will decrease the rate of surface depletion as well (33). Ambient temperature burial of glasses ABS 39 and 41 show evidence of less than 0.1 to $0.3 \mu \mathrm{m}$ of surface attack after $1 \mathrm{yr}$. If this slow rate were to continue throughout the $10^{5} \mathrm{yr}$ of the post-thermal period of storage, it would result in an additional depletion depth of at most 1 to $3 \mathrm{~cm}$. However, the thickness of reaction layers in natural glass analogues exposed to weather- 
ing at ambient temperatures indicate that depletion depths of only a few mm or less are more likely. For example, Allen (103) has shown that a naturally occurring volcanic glass of basaltic composition, containing only $\sim 50 \% \mathrm{SiO}_{2}$ and $20 \% \quad \mathrm{R}_{2} \mathrm{O}$ and $\mathrm{ROs}$, formed a surface alteration layer $<100 \mu \mathrm{m}$ thick after 10 million $\mathrm{yr}$ of exposure to water or hydrothermal fluids. Surface alteration is essentially absent even after this extreme time under dry conditions. Allen concludes that the formation of the claylike, cryptocrystalline palagonite layer on the glass protects it from further alteration. Data from longerterm nuclear waste glass burial experiments now in progress will provide a quantitative base for checking this important conclusion.

\section{RELATION TO POSTCLOSURE RISKS IN GEOLOGIC REPOSITORIES}

The most probable process for release of radionuclides to humans from a closed, deep geologic nuclear repository is leaching of radionuclides from the waste form and subsequent groundwater transport of the radionuclides to the biosphere. A computer code, MISER, has been used by Cheung $e t$ al. (104) to forecast quantitatively the transport and behavior of radionuclides in repositories. Their results describe the effects of repository system design in a probabilistic framework in both near-field and far-field. Uncertainties in wasteform release rate, package properties, and geotechnical data are accounted for with Monte Carlo techniques.

Results from this postclosure risk assessment show that for both generic layered-salt and basalt repositories, the limiting individual peak dose rate is less than 0.1 rem background radiation for both alkali borosilicate glass and polyphase ceramic wasteforms. Cheung et al. (104) conclude that "the difference in performance between the two wasteforms [glass and ceramic] is insignificant." They also conclude that when the doses are sensitive to uncertainties in leaching rates, the doses are orders of magnitude below background. This conclusion is illustrated by Fig. 18 which is based upon the "best estimate" calculation by Chung et al. (104). Figure 18 shows that even alkali borosilicate nuclear waste glasses leached under $90^{\circ} \mathrm{C}, \mathrm{MCC}-1$ static leach conditions of low $S A / V\left(0.1 \mathrm{~cm}^{-1}\right)$ result in limiting individual dose rates that are only $1 / 10$ of background radiation (Fig. 18, point $\mathrm{A}_{3}$ ). When more realistic repository leach conditions are considered, such as the lower temperatures after $300-500$ yrs (point $A_{1}$ ), the individual peak dose rate drops even further to $1 / 50$ background. Note that point $\mathrm{A}_{1}$ is for low $S A / V$ lab test data for borosilicate glass with real SRP waste (18). When the high $S A / V$ and low flow conditions characteristic of repositories are considered, the peak

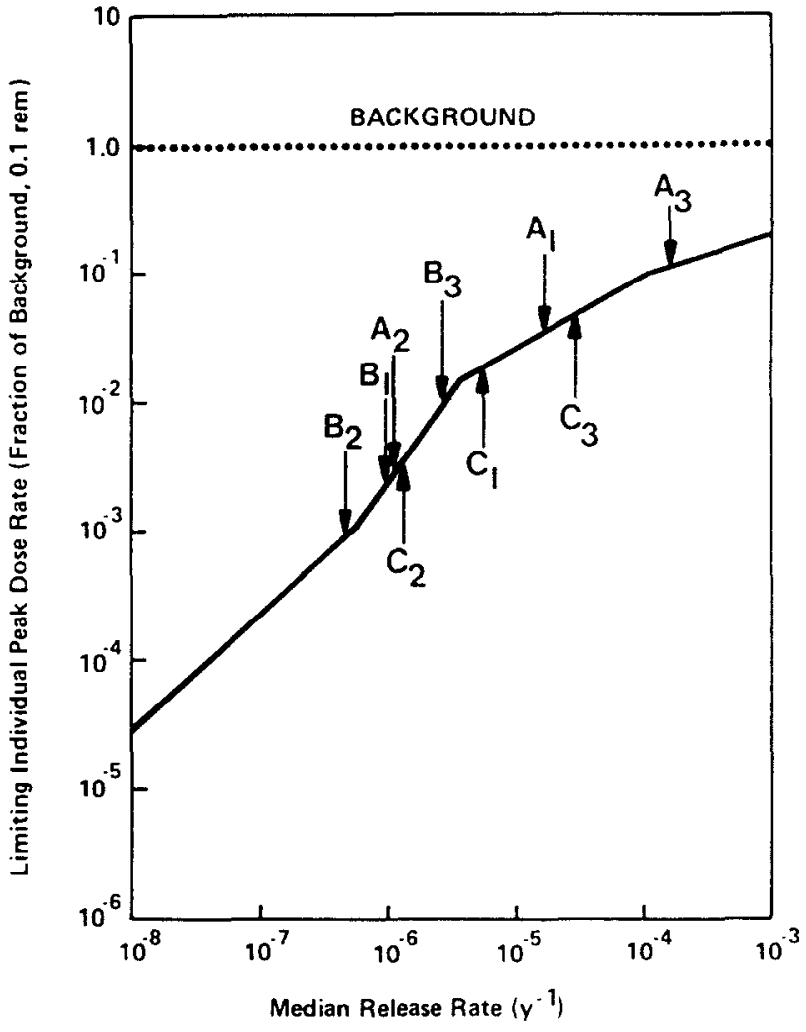

FIGURE 18. Comparison of limiting individual peak dose rates, best estimate calculation from reference 110, for waste glasses with varying lab and burial test conditions: $A_{1}=$ SRL 131 BSG $+30 \%$ SRP HLW (40\%, DI, 36d, MCC-1); $A_{2}=$ SRL 131 BSG $+30 \%$ SIM HLW ( $90^{\circ} \mathrm{C}, 1$ month, STRIPA burial); $A_{3}=$ SRL 131 BSG $+30 \%$ SIM HLW $\left(90^{\circ} \mathrm{C}, 0.1 \mathrm{~cm}^{-1}, \mathrm{DI}, \mathrm{MCC}-1\right) ; \mathrm{B}_{1}=\mathrm{ABS}$ $41 \mathrm{BSG}+9 \%$ SIM HLW; glass/glass $\left(90^{\circ} \mathrm{C}, 1\right.$ yr STRIPA burial); $\mathrm{B}_{2}=\mathrm{ABS} 41 \mathrm{BSG}+9 \%$ SIM HLW; glass $/$ granite $\left(90^{\circ} \mathrm{C}, 1 \mathrm{yr}\right.$ STRIPA burial); $B_{3}=$ ABS 41 BSG $+9 \%$ SIM HLW; glass/ bentonite $\left(90^{\circ} \mathrm{C}, 1 \mathrm{yr}\right.$ STRIPA burial); $\mathrm{C}_{1}=\mathrm{ABS} 39 \mathrm{BSG}+9 \%$ SIM HLW; glass/glass; $\mathrm{C}_{2}=$ ABS 39 BSG $+9 \%$ SIM HLW; glass/granite; $C_{3}=$ ABS 39 BSG +9\% SIM HLW; glass/bentonite.

dose rate value becomes trivially small, $1 / 100$ to $1 / 1000$ of background; see points $A_{2} ; B_{1,2,3}$, and $\mathrm{C}_{1,2,3}$. The release rate data for these nuclear waste glasses is based upon the conservative estimates from the 1 -yr burial experiments, discussed in the previous section. This is a conservative estimate, since it does not consider the decrease in waste form temperatures or the accumulation of radionuclides in the glass surface film. When these factors are taken into account, it is likely that the limiting individual peak dose rates will be no more than $10^{-4}$ of background, as calculated by the methods of Cheung et al. (104).

\section{REFERENCES}

1. Mendel, J. E. High-level waste glass. Nucl. Technol. 32, 72 (1977).

2. Scientific Basis for Nuclear Waste Management V, MRS Symposia Proceedings, Vol. 11, W. Lutze, ed., pp. 1-299. Elsevier Science Publishing Co., New York (1982).

3. Grambow, B. and Lutze, W. Chemical stability of a phos- 
phate glass under hydrothermal conditions, in Scientific Basis for Nuclear Waste Management, Vol. 2, C. J. M. Northrup, Jr., ed. Plenum Press, New York (1980).

4. Watson, L. C., Aiken, A. M., and Bancroft, A. R. Disposal of radioactive wastes, pp. 379-393. STI/PUB/18, IAEA, Vienna (1960).

5. McCarthy, G. J. and Davidson, M. T. Ceramic nuclear waste forms: 1, Crystal chemistry and phase formulation. Ceramic Bull. 54, 782 (1975).

6. Ringwood, A. E., Kesson, S. E., Ware, N. G., Hibberson, W., and Major, A. Immobilization of high level nuclear reactor wastes in SYNROC. Nature 278, 219 (1979).

7. Moore, J. G., Rogers, G. C., Katz, S., Morgan, M. T., and Newman, E. FUETAP concretes - Tailored autoclaved concretes for the fixation of radioactive wastes. Waste Management '81, Volume 1, p. 267. University of Arizona, Tucson, AZ (1981).

8. Bernadzikowski, T. A., ed. The evaluation and selection of candidate high level waste forms. USDOE/TIC-11611, National Technical Info. Service, Springfield, VA (1982).

9. The evaluation and review of alternative waste forms for inmobilization of high-level radioactive wastes. Report number 1, DOE/TIC-10228, United States Department of Energy, Alternative Waste Form Peer Review Panel Washington, DC (1979).

10. The evaluation and review of alternative waste forms for immobilization of high-level radioactive wastes. Report number 2, DOE/TIC-11219, United States Department of Energy, Alternative Waste Form Peer Review Panel Washington, DC (1980).

11. The evaluation and review of alternative waste forms for immobility of high-level radioactive wastes. Report number 3, DOE/TIC-11472, United States Department of Energy, Alternative Waste Form Peer Review Panel Washington, DC (1981).

12. A method for product performance evaluation of candidate waste forms for immobilization of high-level radioactive wastes. DOC/TIC-11612, United States Department of Energy, Interface Working Group on High-Level Waste Form Selection Factors, Washington, DC (1982).

13. Dunson, J. B., Eisenberg, A. M., Schuyler, R. L., Du Pont Engineering Department, Gould, T. H., Butler, J. L., and Pickett, J. B. Savannah River Laboratory, assessment of processes, facilities, and costs for alternative solid forms for immobilization of SRP defense waste. DP-1625, Savannah River Laboratory, Aiken, SC (1982).

14. E. R. Johnson Associates, Inc. Preliminary evaluation of alternative waste form solidification processes, Volume II: Evaluation of the processes. PNL-3477, Pacific Northwest Laboratory Richland, WA (1980).

15. Radioactive glasses: research and testing, p. 269. CEA Group, Editions MSA, Paris (1982).

16. Sombret, C., Bonniard, R. and Jovani, A. Large scale waste glass production, in Proceedings of the Conference on High Level Radioactive Solid Waste Forms, L. A. Casey, ed. U.S. Nuclear Regulatory Commission, Washington, DC. (1979).

17. Wicks, G. G. Vitrification of simulated high level radioactive waste by a slurry-fed ceramic melter, Nuclear Technol. 55, 601 (1981).

18. Plodinec, M. J., Soper, P. D., Bibler, N. E., and Kessler, J. L. SRP radioactive glass studies: Small-scale process development and product performance. SRL Report DPMS-82-26 Rev., Savannah River Laboratory, Aiken, SC (1982).

19. Jantzen, C. M., Bickford, D. F., and Karraker, D. G. Timetemperature-transformation kinetics in SRL waste glass, in Nuclear Waste Management. Advances in Ceramics, Vol. 8, G. G. Wicks and W. A. Ross, eds., p. 30. American Ceramic Society, Columbus, OH (1984).
20. Campbell, J. H., Hoenig, C. L., Ackerman, F. J., Peters, P. E., and Grens, J. Z. Incorporation of high-level wastes in SYNROC: Results from recent process engineering studies at Lawrence Livermore National Laboratory, in Scientific Basis for Radioactive Waste Management, Vol. 5, W. Lutze, ed., p. 299. Elsevier, New York (1982).

21. Newby, D. (Westinghouse Electric Corp.) Engineered waste package conceptual design defense: High level waste (Form 1), commercial high level waste (Form 1) and spent fuel (Form 2) disposal in salt. ONWI-438, prepared for Office of Nuclear Waste Isolation, Battelle Memorial Institute, Columbus, $\mathrm{OH},(1983)$.

22. De Wames, R. E., Grantham, L. F., Guon, J., and McKisson, R. L. Economic optimization of nuclear waste management, in Nuclear Waste Management. Advances in Ceramics, Vol. 8, G. G. Wicks and W. A. Ross, eds., p. 652. American Ceramic Society, Columbus, OH (1984).

23. Materials Characterization Center (MCC) Test Methods, Preliminary Version. PNL 3990, Pacific Northwest Laboratory, Richland, WA (1981).

24. Hench, A. A. and Hench, L. L. Computer analysis of compositional effects in nuclear waste glass leaching. $\mathrm{Nucl}$. Chem. Waste Management (in press).

25. Strachan, D. M. Results from a one-year leach test: Long term use of MCC-1, in Scientific Basis For Nuclear Waste Management, Vol. 5, W. Lutze, ed., p. 181. Elsevier, New York (1982).

26. Nogues, J. L., Hench, L. L., and Zarzycki, J. Comparative study of seven glasses for solidification of nuclear wastes, in Scientific Basis For Nuclear Waste Management Vol. 5, W. Lutze, ed., p. 211. Elsevier, New York (1982).

27. Walker, D. D., Wiley, J. R., Dukes, M. D., and LeRoy, J. $\mathrm{H}$. Leach rate studies on glass containing actual radioactive waste, in Abstracts from ORNL Conference on the Leachability of Radioactive Solids, Savannah River Laboratories, Aiken, SC.

28. Hench, L. L. Glass surfaces-1982. J. Phys. Colloque C9, Suppl. au no. 12, 43, 625 (1982).

29. Clark, D. E. and Hench, L. L. Theory of corrosion of alkaliborosilicate glass, in Scientific Basis for Nuclear Waste Management, Vol. 6, D. G. Brookins, ed., p. 113. Elsevier, New York (1983).

30. Barkatt, A., Macedo, P. B., Sousanpour, W., Barkatt, A. Boroomand, M. A., Szoke, P., and Rogers, V. L. Correlation between dynamic leach test results and geochemical observations, in Scientific Basis for Nuclear Waste Management, Vol. 6, D. G. Brookins, ed., p. 227. Elsevier, New York (1983).

31. Wallace, R. M. and Wicks, G. C. Leaching chemistry of defense borosilicate glass, in Scientific Basic for Nuclear Waste Management, Vol. 6, D. G. Brookins, ed., p. 23. Elsevier, New York (1983).

32. Kuhn, W. L. and Peters, R. D. Leach models for a commercial nuclear waste glass, in Scientific Basis for Nuclear Waste Management, Vol. 6, D. G. Brookins, ed., p. 167. Elsevier, New York (1983).

33. Altenheim, F, K., Lutze, W., and Ewing, R. C. Long-term radioactivity release from solidified high level waste-Part II, Parametric study of waste form properties, temperature and time, in Scientific Basis for Nuclear Waste Management, Vol. 6, D. G. Brookins, ed., p. 269. Elsevier, New York (1983).

34. Lutze, W., Malow, G., Rabe, H., and Headley, T. J. Surface layer formation on a nuclear waste glass, in Scientific Basis for Nuclear Waste Management, Vol. 6, D. G. Brookins, ed., p. 37. Elsevier, New York (1983).

35. Grambow, $B$. The role of metal ion solubility in leaching of nuclear waste glasses, in Scientific Basis for Radioactive Waste Management, Vol. 6, W. Lutze, ed., p. 93. Elsevier, 
New York (1982).

36. Hench, L. L. Werme, L., and Lodding, A. Burial effects on nuclear waste glass, in Scientific Basis for Nuclear Waste Management, Vol. 5, W. Lutze, ed., p. 153. Elsevier, New York (1982).

37. Werme, L., Hench, L. L., and Lodding, A. Effect of overpack materials on glass leaching in geological burial, in Scientific Basis For Nuclear Waste Management, Vol. 5, W. Lutze, ed., p. 135. Elsevier, New York (1982).

38. Hench, L. L. and Wilson, M. R. Nuclear waste glass interfaces after one year burial in STRIPA: Part 3, Comparative surface profiles (in press).

39. Clark, D. E., Pantano, C. F., and Hench, L. L. Glass Corrosion. Books for Industry, New York (1979).

40. Hench, L. L., Clark, D. E., and Lue Yen-Bower, E. Corrosion of glasses and glass-ceramics. Nucl. Chem. Waste Management 1, 59 (1980).

41. Chick, L. A., McVay, G. L., Mellinger, G. B., and Roberts, F. P. PNL Report 3465, Battelle Memorial Institute, (1980).

42. Materials Characterization Center. A state-of-the-art review of materials properties of nuclear waste forms. PNL-3802, Battelle Pacific Northwest Laboratory, Richland, WA (1981).

43. Plodinec, M. J., Wicks, G. G., and Bibler, N. E. An assessment of Savannah River borosilicate glass in the repository environment. Report DP-1629, Savannah River Laboratory, Aiken, SC (1982).

44. McVay, G. L. and Buckwalter, C. Q. Nucl. Technol. 51, (1980).

45. Clark, D. E., Maurer, C. A., Jurgensen, A. R., and Urwongse, L. Effects of waste composition and loading on the chemical durability of a borosilicate glass, in Scientific Basis for Nuclear Waste Management, Vol. 5, W. Lutze, ed., p. 1. Elsevier, New York (1982).

46. Wicks, G. G. Proceedings of Waste Management 1981 Conference, Tucson, AZ, Feb. 23-27 (1981).

47. Wicks, G. G., Robnett, B. M., and Rankin, W. E. Chemical durability of glass containing SRP waste - Leachability characteristics, protective layer formation, and repository system interactions, in Scientific Basis for Nuclear Waste Management, Vol. 5, W. Lutze, ed., p. 15. Elsevier, New York (1982).

48. Hench, L. L., Lodding, A., and Werme, L. Analysis of one year in situ burial of nuclear waste glasses in Stripa, in Nuclear Waste Management. Advances in Ceramics, Vol. 8, G. G. Wicks and W. A. Ross, eds., p. 310. American Ceramic Society, Columbus, $\mathrm{OH}$ (1984).

49. Clark, D. E., Zhu, B. F., Robinson, R. S., and Wicks, G. G. Preliminary report on a glass burial experiment in granite, in Nuclear Waste Management. Advances in Ceramics, Vol. 8, G. G. Wicks and W. A. Ross, eds., p. 324. American Ceramic Society, Columbus, $\mathrm{OH}$ (1984).

50. Coles, P. G. et al. Single pass leaching of nuclear melt glass by ground water. Presented at the ACS Symposium Series 100 , Radioactive Waste in Geologic Storage, American Chemical Society, Washington, DC (1978).

51. Strachan, D. M., Barnes, B. O., and Turcotte, R. P. Standard leach tests for nuclear waste materials, in Scientific Basis for Nuclear Waste Management, Vol. 3, J. G. Moore, ed., p. 347. Plenum Press, New York (1981).

52. Macedo, P. B., Barkatt, A., and Simmons, J. H. A flow model for the kinetics of dissolution of nuclear waste glasses. Nucl. Chem. Waste Management 3, 13 (1982).

53. Clark, D. E., Christensen, H., Hermansson, H.-P., Sund vall, S.-B., and Werme, L. Effects of flow on corrosion and surface film formation on an alkali borosilicate glass, in Nuclear Waste Management. Advances in Ceramics, Vol. 8, G. G. Wicks and W. A. Ross, eds., p. 19. American Ceramic Society, Columbus, OH (1984).
54. Paul. A. Chemical durability of glasses: A thermodynamic approach. J. Mater. Sci. 12, 2246 (1977).

55. Newton, R. G. and Paul, A. A new approach to predicting the durability of glasses from their chemical compositions. Glass Technol. 21, 307 (1980).

56. Plodinec, M. J., Jantzen, C. M., and Wicks, G. G. A thermodynamic approach to prediction of the stability of proposed radwaste glasses, in Nuclear Waste Management. Advances in Ceramics, Vol. 8, G. G. Wicks and W. A. Ross, eds., p. 491. American Ceramic Society, Columbus, $\mathrm{OH}$ (1984).

57. Bibler, N. E. Effects of alpha, gamma, and alpha-recoil radiation on borosilicate glass containing Savannah River Plant defense high-level nuclear waste, in Scientific Basis for Nuclear Waste Management, Vol. 6, Stephen V. Topp, ed., p. 681. Elsevier, New York (1982).

58. Kelly, J. A. Evaluation of glass as a matrix for solidification of Savannah River Plant waste, radioactive studies. DP-1397, E. I. du Pont de Nemours and Company, Savannah River Laboratory, Aiken, SC (1975).

59. Walker, D. D., Dukes, M. D., Plodinec, M. J., and Bibler, N. E. Effect of radiation on leaching of borosilicate glass containing defense high level nuclear waste. Savannah River Laboratory, E. I. du Pont de Nemours \& Co., Aiken, SC.; presented at the 181st National Meeting of the American Chemical Society, March 30-April 3, Atlanta, GA (1981).

60. McVay, G. L. and Pederson, L. R. Effect of gamma radiation on glass leaching. J. Amer. Ceram. Soc. 64154 (1981).

61. Hermansson, H. P., Christensen, H., Clark, D. E., Bjorner, I.-K., Yokoyama, H., and Werme, L. Static leaching of radioactive glass under conditions simulating a granitic repository for high level waste: Phase 1. MRS Boston Meeting (1983).

62. Turcotte, R. P., Wald, J. W., Roberts, F. P., Rusin, J. M., and Lutze, W. Radiation damage in nuclear waste ceramics. J. Amer. Ceram. Soc. 65, 589 (1982).

63. Weber, W. J. A review of the current status of radiation effects in solid nuclear waste forms, in Scientific Basis for Nuclear Waste Management, Vol. 6, D. G. Brookins, ed., p. 407. Elsevier, New York (1983).

64. Malow, G., Marples, J. A. C., and Sombret, C. Thermal and radiation effects on properties of high-level waste products, in the Proceedings of the First European Community Conference on Radioactive Waste Management Disposal, P. Simon and S. Orlowski, eds., p. 341. Harwood Academic Publishers, Chur, Switzerland, (1980).

65. Turcotte, R. P. and Wald, J. W. Devitrification behavior in a zinc borosilicate nuclear waste glass. PNL-2247, Pacific Northwest Laboratory, Richland, WA (1978).

66. Ross, W. A., Bradley, D. J., Bunnell, L. R., Gray, W. J., Katayama, Y. B., Mellinger, G. B., Mendel, J. E., Roberts, F. P., Turcotte, R. P., Wald, J. W., Weber, W. E., and Westsik, J. H. Jr. Annual report on the characterization of high-level waste glasses. PNL-2625, Battelle Pacific Northwest Laboratory Richland, WA (1978).

67. Hatch, L. P. Amer. Scientist 41, 410 (1953).

68. Ringwood, S. E., Kesson, S. E., Ware, N. G., Hibberson, W. O., and Major, A. Geochem. J. 13, 141 (1979).

69. Campbell, J. H., Hoenig, C. L., Bazan, F., Ryerson, F. J., and Rozsa, R. Immobilization of Savannah River high-level wastes in Synroc: Results from product performance tests, in Scientific Basis for Nuclear Waste Management, Vol. 6, S. V. Topp, ed., p. 49. Elsevier, New York (1982).

70. Morgan, P. E. D., Clarke, D. R., Jantzen, C. M., and Harker, A. B. J. Amer. Ceram. Soc. 64, 249 (1981).

71. McCarthy, G. J. Amer. Nucl. Soc. Trans. 23, 168 (1976).

72. Roy, R. J. Amer. Ceram. Soc. 60, 350 (1977).

73. Ringwood, A. E., Kesson, S. E., Ware, N. G., Hibberson, W., and Major, A. Nature 278, 219 (1979). 
74. Ringwood, A. E., Kesson, S. E., and Ware, N. G. Immobilization of U.S. defense waste using Synroc process, in Scientific Basis for Nuclear Waste Management, Vol. 2, J. G. Moore, ed., p. 265. Plenum Press, New York (1980).

75. Harker, A. B., Morgan, P. E. D., Flintoff, J. F., and Clarke, D. R. An improved polyphase ceramic for high-level defense waste, Proceedings of the ANS Topical Meeting on the Treatment and Handling of Radioactive Wastes, p. 335. Battelle Press, Columbus, OH (1982).

76. Harker, A. B. and Flintoff, J. F. Hot isostatically pressed ceramic and glass forms for immobilizing Hanford high-level wastes, in Nuclear Waste Management. Advances in Ceramics, Vol. 8, G. G. Wicks and W. A. Ross, eds., p. 222. American Ceramic Society, Columbus, OH (1984).

77. Harker, A. B., Morgan, P. E. D., Clarke, D. R., and Flintoff, J. F. Formulation and processing of polyphase ceramics for high level nuclear waste, in Scientific Basis for Nuclear Waste Management, Vol. 6, Stephen V. Topp, ed., p. 567. Elsevier, New York (1982).

78. Morgan, P. E. D., Shaw, T. M., and Pugar, E. Ceramics for high waste loaded commercial radwaste disposal, in Nuclear Waste Management, Advances in Ceramics, Vol. 8, G. G. Wicks and W. A. Ross, eds., p. 209. American Ceramic Society, Columbus, $\mathrm{OH}$ (1984).

79. Morgan, P. E. D., Harker, A. B., Flintoff, J. F., Shaw, T. M., and Clarke, D. R. Developments in 'composite' defense ceramic radwaste forms, in Nuclear Waste Management. Advances in Ceramics, Vol. 8, G. G. Wicks and W. A. Ross, eds., p. 234. American Ceramic Society, Columbus, $\mathrm{OH}$ (1984).

80. Grantham, L. F., McKisson, R. L., Guon J., Flintoff, J. F., and McKenzie, D. E. Process description and plant design for preparing ceramic high-level waste forms. DOE/ET/ 41900-16 (ESG-DOE-13397), Rockwell International Energy Systems Group, Canoga Park, CA (1983).

81. Harker, A. B., Clarke, D. R., Jantzen, C. M., and Morgan, P. E. D. The effect of interfacial material on tailored ceramic nuclear waste form dissolution, in Surfaces and Interfaces in Ceramic and Ceramic-Metal Systems, Materials Science Res., Vol. 14, J. Pask and A. Evans eds., p. 207. Plenum Press, New York (1981).

82. Clarke, D. R. and Flintoff, J. F. Preferential dissolution phenomena of nuclear waste materials, in Scientific Basis for Nuclear Waste Management, Vol. 6, D. G. Brookins, ed., p. 29. Elsevier, New York (1983).

83. Ryerson, F. J. Synroc-D: Microstructure and mineral chemistry. UCRL-88458, Lawrence Livermore National Laboratory Livermore, CA (1983).

84. Hoenig, C. L., Rozsa, R. B., Otto, R., and Grens, L. Preparation and properties of Synroc-D for Savannah River Plant high-level defense waste. UCRL-53195, Lawrence Livermore National Laboratory, Livermore, CA (1981).

85. Campbell, J., Hoenig, C., Bazan, F., Ryerson, F., Guinan, M., Van Konynenburg, R. and Rozsa, R. Properties of synroc-D nuclear waste form: A state-of-the-art review. UCRL-53240, Lawrence Livermore National Laboratory, Livermore, CA (1982).

86. Campbell, J. H., Ryerson, F. J., Rozsa, R. B., and Hoenig, C. L. Flexibility in formulating and processing Synroc-D: A current assessment. UCRL-87349, Lawrence Livermore National Laboratory, Livermore, CA (1982).

87. Ryerson, F. J., Burr, K., and Rozsa, R. Formulating of Synroc-D additives for Savannah River Plant high-level radioactive wastes. UCRL-53237, Lawrence Livermore National Laboratory, Livermore, CA (1981).

88. Campbell, J. H., Rozsa, R. B., and Hoenig, C. L. Immobilization of high-level defense wastes in Synroc-D: Recent R\&D results on process scale-up UCRL-86558, Lawrence Livermore National Laboratory, Livermore, CA
(1982).

89. Hoenig, C., Otto, R., and Campbell, J. Densification studies of Synroc-D for high-level defense waste. UCRL-53392, Lawrence Livermore National Laboratory, Livermore, CA (1983).

90. Ackerman, F. I., Grens, J. 7., Ryerson, F. J., Hoenig, C. L., Bazan, F., and Campbell, J. H. Synroc production using a fluidized-bed calciner. UCRL-87742, Lawrence Livermore National Laboratory, Livermore, CA (1982).

91. Rozsa, R. B. and Campbell, J. H. Disposal costs for SRP high-level wastes in borosilicate glass and crystalline ceramic waste forms. UCRL-53315, Lawrence Livermore National Laboratory, Livermore, CA (1982).

92. Papadakis, E. P. J. Acous. Soc. Amer. 52 (1972).

93. Jardine, L. J., Reedy, G. T., and Mecham, W. J. Respirable fines produced by impacts of simulated alternative high-level waste materials, in Scientific Basis for Nuclear Waste Management, S. V. Topp, ed., p. 115. Elsevier, New York (1982).

94. Hench, L. L., Clark, D. E., and Maurer, C. Baseline repository conditions. Leaching Mechanisms Program Report presented at the Thousand Oaks, California Workshop, December 7 (1982).

95. Hermansson, H.-P., Christensen, H., Clark, D. E., and Werme, L. Effects of solution chemistry and atmosphere on leaching of alkali borosilicate glass, in Scientific Basis for Nuclear Waste Management, Vol. 6, D. G. Brookins, ed., p. 143. Elsevier, New York (1983).

96. Malow, G. The mechanisms for hydrothermal leaching of nuclear waste glasses: Properties and evaluation of surface layers, in Scientific Basis for Radioactive Waste Management, Vol. 5, W. Lutze, ed., p. 347. Elsevier, New York (1982).

97. van Iseghem, P., Timmermans, W., and de Batist, R. Chemical stability of simulated HLW forms in contact with clay media, in Scientific Basis for Radioactive Waste Management, Vol. 5, W. Lutze, ed., p. 219. Elsevier, New York (1982).

98. Hench, L. L., Werme, L. and Lodding, A. Nuclear waste glass interfaces after one year burial in STRIPA, Part 3: Glass/granite, (in press).

99. Chickalla, T. D. and Powell, J. A. Nuclear waste management quarterly progress report, Oct.-Dec., 1980. PNL-30008/4C-70, Pacific Northwest Laboratory, Richland, WA (1981).

100. Savage, D. and Robbins, J. E. The interaction of borosilicate glass and granodiarite at $100^{\circ} \mathrm{C}, 50 \mathrm{MKPa}$ : Implications for models of radionuclide release, in Scientific Basis for Nuclear Waste Management, Vol. 5, W. Lutze, ed., p. 145. Elsevier, New York (1982).

101. Pederson, L. L., Buchwalter, C. Q., McVay, G. C., and Riddle, B. L. Glass surface area to solution volume ratio and its implications to accelerated leach testing, in Scientific Basis for Nuclear Waste Management, Vol. 6, D. G. Brookins, ed., p. 47. Elsevier, New York (1983).

102. McVay, G. L., and Buckwalter, C. Q. The effect of iron on waste glass leaching. PNL-SA-10474, Battelle Pacific Northwest Laboratory, Richland, WA (1982).

103. Allen, C. C. Stability and alteration of naturally occurring low-silica glasses: Implications for the long term stability of waste form glasses, in Scientific Basis for Radioactive Waste Management, Vol. 5, W. Lutze, ed., p. 37. Elsevier, New York (1982).

104. Cheung, H., Edwards, L. L., Harvey, T. F. Nuclear wasteform risk assessment for U.S. defense waste at Savannah River Plant, Annual Report FY 1982. Report UCRL-53188-82, Lawrence Livermore Laboratory, (1982).

105. Freeborn, W. P., Zoelensky, M., Scheetz, M., Komarneni, S., McCarthy, G. J., and White, W. B. Hydrothermal interac- 
tions between calcine, glass, spent fuel, and ceramic waste, forms with representative shale repository rocks. Materials Research Laboratory, Pennsylvania State University, University Park, PA (1982).

106. Chickalla, T. D. and Powell, J. A. Nuclear waste management quarterly progress report, Oct.-Dec., 1980, PNL-30008/4C-70, Pacific Northwest Laboratory, Richland, WA (1981).

107. Chick, L. A., McVay, G. L., Mellinger, G. B., and Roberts, F. P. Annual report on the development and characterization of solidified forms for nuclear wastes, 1979. PNL-3465/UC-70, Pacific Northwest Laboratory, Richland, WA (1980).

108. Ross, W. A., and Mendel, J. E. Annual report on the development and characterization of solidified forms for high-level wastes, 1978. [PNL-3060/UC-70, Pacific Northwest Laboratory, Richland, WA (1979).

109. Solomah, A. G. and Zumwalt, L. HLW fixation in sintered modified Synroc-B ceramics: Chemical stability evaluation. Trans. Amer. Nucl. Soc. 35, 191 (1980).

110. Hall, A. R., Hough, A., and Marples, J. A. C. Leaching of vitrified high level waste, in Scientific Basis for Nuclear Waste Management, Vol. 5, W. Lutze, ed., p. 83. Elsevier,
New York (1982).

111. Hayward, P. J., Hocking, W. H., Doern, F. E., and Cecchetto, E. V. SIMS depth profiling studies of sphene-based ceremics and glass ceramics leached in synthetic groundwater, in Scientific Basis for Nuclear Waste Management, Vol. 5, W. Lutze, ed., p. 319. Elsevier, (1982).

112. Merritt, W. F., and Parsons, P. J. The safe burial of highlevel fission product solutions incorporated into glass. Health Phys. 10, 655 (1964).

113. Merritt, W. F. High level waste glass: Field leach test. Nucl. Technol. 32, 88 (1977).

114. Fletcher, W. W. The chemical durability of glass. Progress report on burial experiments at Ballidon and Wareham, England. Unpublished (1974).

115. Clark, D. E. and Maurer, C. A. Waste glass/repository interactions, in Scientific Basis for Nuclear Waste Management, Vol. 5, W. Lutze, ed., p. 71. Elsevier, New York (1982).

116. Clark, D. E., Urwongse, L., and Maurer, C. Application of glass corrosion concepts to nuclear waste immobilization. Nucl. Technol. 56, 212 (1982). 